University of South Florida

DIGITAL COMMONS

@ UNIVERSITY OF SOUTH FLORIDA
Digital Commons @ University of

South Florida

4-1-2003

\title{
Assessment of Transit Information Materials and Development of Criteria for Prototype Transit Materials
}

CUTR

Follow this and additional works at: https://digitalcommons.usf.edu/cutr_nctr

\section{Scholar Commons Citation}

CUTR, "Assessment of Transit Information Materials and Development of Criteria for Prototype Transit Materials" (2003). Research Reports. 214.

https://digitalcommons.usf.edu/cutr_nctr/214

This Technical Report is brought to you for free and open access by the National Center for Transit Research (NCTR) Archive (2000-2020) at Digital Commons @ University of South Florida. It has been accepted for inclusion in Research Reports by an authorized administrator of Digital Commons @ University of South Florida. For more information, please contact digitalcommons@usf.edu. 


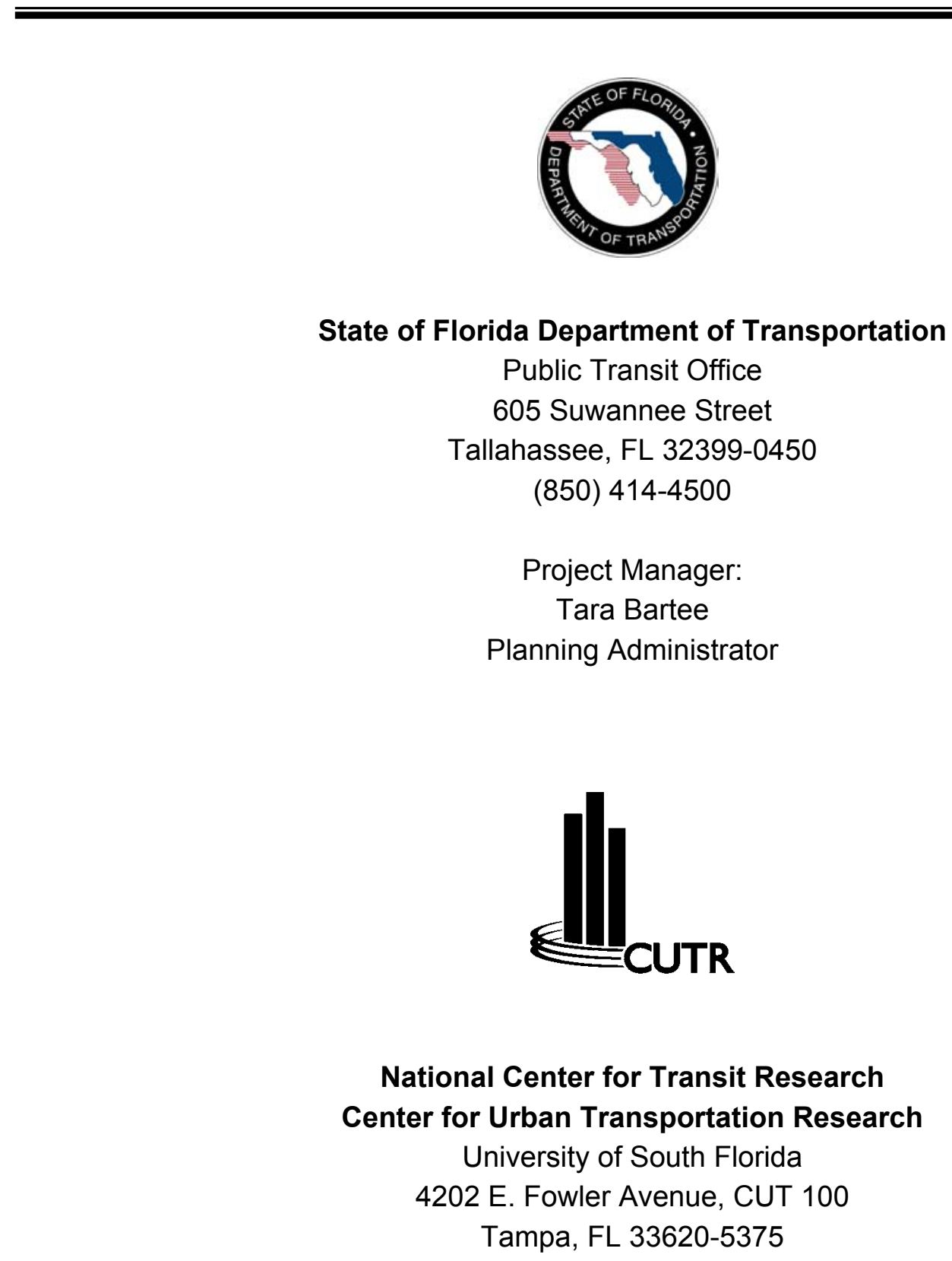

(813) 974-3120

Project Director: Dennis Hinebaugh, Transit Program Director

Project Manager: $\quad$ Chandra C. Foreman, Research Associate

Project Staff: $\quad$ Lisa Tucker, Research Associate

Michael West, Research Assistant

Prepared in cooperation with the Florida Department of Transportation and the United States Department of Transportation. The opinions, findings and conclusions expressed in this publication are those of the authors and not necessarily those of the U.S. Department of Transportation or the State of Florida Department of Transportation. 
TECHNICAL REPORT STANDARD TITLE PAGE

\begin{tabular}{|c|c|c|c|}
\hline $\begin{array}{l}\text { 1. Report No. } \\
\text { NCTR } 473-12\end{array}$ & 2. Government Accession No. & \multicolumn{2}{|c|}{\begin{tabular}{|l} 
3. Recipient's Catalog No. \\
\end{tabular}} \\
\hline \multirow{2}{*}{\multicolumn{2}{|c|}{$\begin{array}{l}\text { 4. Title and subtitle } \\
\text { Assessment of Transit Information Materials and Development } \\
\text { of Criteria for Prototype Transit Materials }\end{array}$}} & \multicolumn{2}{|c|}{$\begin{array}{l}\text { 5. Report Date } \\
\text { April } 2003\end{array}$} \\
\hline & & \multicolumn{2}{|c|}{ 6. Performing Organization Code } \\
\hline \multicolumn{2}{|l|}{$\begin{array}{l}\text { 7. Author(s) } \\
\text { Chandra Foreman and Lisa Tucker }\end{array}$} & \multicolumn{2}{|c|}{ 8. Performing Organization Report No. } \\
\hline \multirow{2}{*}{\multicolumn{2}{|c|}{$\begin{array}{l}\text { 9. Performing Organization Name and Address } \\
\text { National Center For Transit Research (NCTR) } \\
\text { University of South Florida CUT } 100 \\
4202 \text { East Fowler Avenue, Tampa, FL } 33620\end{array}$}} & \multicolumn{2}{|l|}{ 10. Work Unit No. } \\
\hline & & \multicolumn{2}{|c|}{$\begin{array}{l}\text { 11. Contract or Grant No. } \\
\text { DTRS98-G-0032 }\end{array}$} \\
\hline \multicolumn{2}{|c|}{$\begin{array}{l}\text { 12. Sponsoring Agency Name and Address } \\
\text { Office of Research and Special Programs (RSPA) } \\
\text { U.S. Department of Transportation, Washington, D.C. } 20590\end{array}$} & \multicolumn{2}{|c|}{ 13. Type of Report and Period Covered } \\
\hline \multicolumn{2}{|c|}{$\begin{array}{l}\text { Florida Department of Transportation } \\
605 \text { Suwannee Street, MS 26, Tallahassee, FL } 32399\end{array}$} & \multicolumn{2}{|c|}{ 14. Sponsoring Agency Code } \\
\hline \multicolumn{4}{|c|}{$\begin{array}{l}\text { 15. Supplementary Notes } \\
\text { Supported by a Grant from the USDOT Research and Special Programs Administration, and the } \\
\text { Florida Department of Transportation }\end{array}$} \\
\hline \multicolumn{4}{|c|}{$\begin{array}{l}\text { 16. Abstract } \\
\text { Through its National Center for Transit Research (NCTR), and under contract with the Florida } \\
\text { Department of Transportation, the Center for Urban Transportation Research expanded upon the } \\
\text { findings of the NCTR Research Project, Assessment of Operational Barriers and Impediments to } \\
\text { Transit Use, wherein the lack of effective and user-friendly bus schedules and route maps in } \\
\text { Florida was identified as a significant barrier to transit use among non-users. The report included } \\
\text { herein is the foundation for a second phase to the above-referenced report, wherein prototype } \\
\text { transit information materials will be developed and field-tested to evaluate the effectiveness of } \\
\text { specific design materials. To prepare for the second phase project, bus schedules and route maps } \\
\text { were collected from national markets to identify best practices in transit information materials. } \\
\text { These materials were classified based on their design elements. A process was also developed to } \\
\text { guide the selection of design elements to be included in prototype materials for the second phase } \\
\text { project. }\end{array}$} \\
\hline $\begin{array}{l}\text { 17. Key Words } \\
\text { Transit Marketing, Bus } \\
\text { Schedules, Route Maps, Transit } \\
\text { Literacy, Schedule Design }\end{array}$ & \multicolumn{3}{|c|}{$\begin{array}{l}\text { 18. Distribution Statement } \\
\text { Available to the public through the National Technical } \\
\text { Information Service (NTIS), 5285 Port Royal Road, Springfield, } \\
\text { VA 22161, (703) 487-4650, http://www.ntis.gov/, and through } \\
\text { the NCTR web site at http://www.nctr.usf.edu/. }\end{array}$} \\
\hline $\begin{array}{l}\text { 19. Security Classif. (of this report) } \\
\text { Unclassified }\end{array}$ & $\begin{array}{l}\text { 20. Security Classifi. (of this page) } \\
\text { Unclassified }\end{array}$ & $\begin{array}{l}\text { 21. No. of pages } \\
40\end{array}$ & 22. Price \\
\hline
\end{tabular}




\section{Table of Contents}

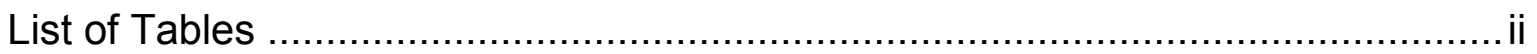

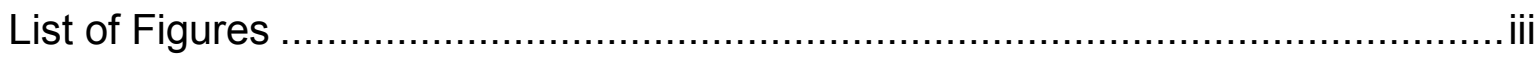

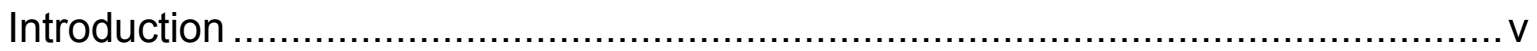

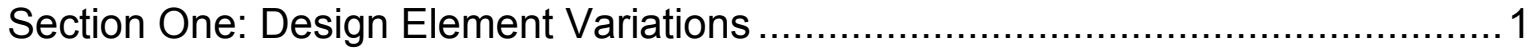

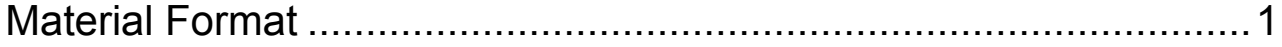

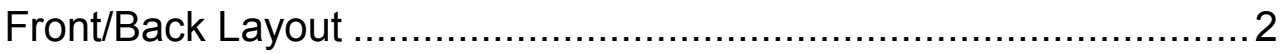

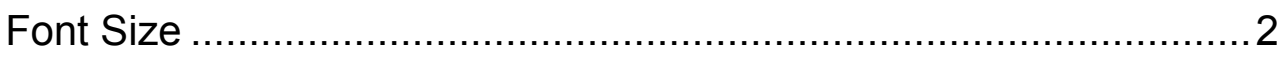

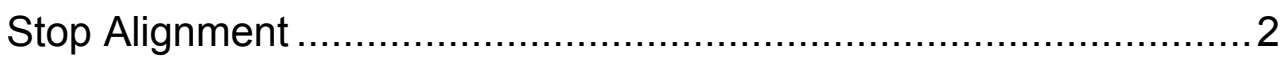

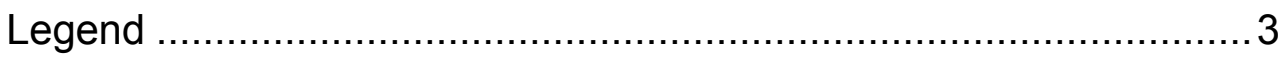

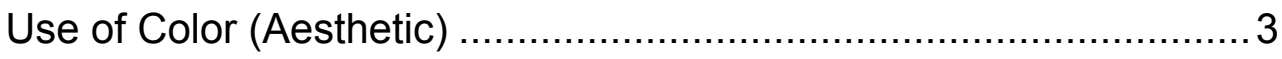

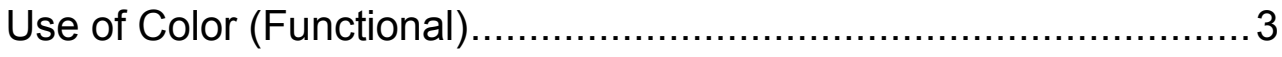

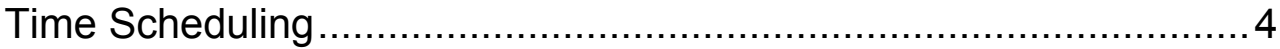

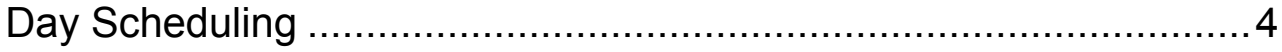

Section Two: Transit Information Materials Database ...................................

Section Three: Process for Design Element Selection.........................................27

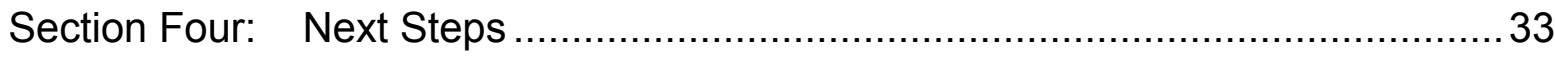




\section{List of Tables}

Table 1 Design Element Variations ..........................................................

Table 2 Transit Schedule/Map Inventory: Info Format............................... 8

Table 3 Transit Schedule/Map Inventory: Front/Back Layout.......................13

Table 4 Transit Schedule/Map Inventory:

Time and Day Scheduling (Florida Systems) .................................. 18

Table 5 Transit Schedule/Map Inventory:

Time and Day Scheduling (Non-Florida Systems) ..........................20

Table 6 Transit Schedule/Map Inventory

Format (Systems with Individual Route Maps) ...............................21

Table $7 \quad$ Transit Schedule/Map Inventory

Format (Systems with Ride Guides) .......................................... 22

Table 8 Transit Schedule/Map Inventory

Color Scheme and Stop Alignment.................................................23

Table 9 Transit Map Inventory: Map Features (Stand-Alone Maps) ..............25

Table 10 Transit Map Inventory: Map Features (Ride Guide Maps) ................26

Table 11 Design Element Evaluation - Feasibility ......................................28

Table 12 Design Element Evaluation - Cost to Test .....................................28

Table 13 Design Element Evaluation - Noted Difficulty in Original Tests.........29

Table 14 Design Element Evaluation -

Perceived Importance to Trip Planning............................................ 30

Table 15 Design Element Selection Matrix.................................................... 31 


\section{List of Figures}

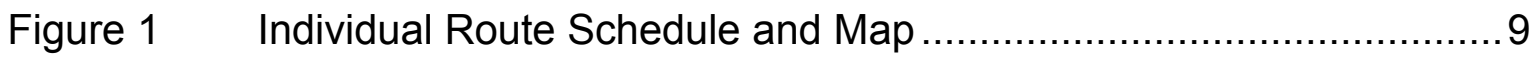

Figure 2 All-In-One Route Guide ....................................................... 10

Figure $3 \quad$ Map and Schedule on Same Page ................................................. 11

Figure $4 \quad$ Map and Schedule on Front and Back of Transit Material................. 12

Figure $5 \quad$ A.M. and P.M. Hours Labeled ................................................ 14

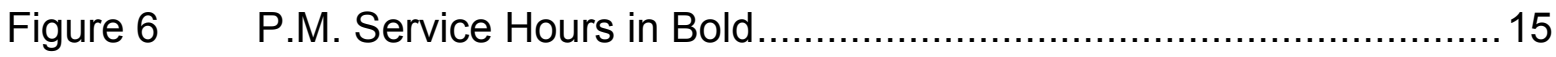

Figure $7 \quad$ Weekday and Saturday Service Shown in Same Table ................... 16

Figure $8 \quad$ Weekday and Saturday Service Show in Separate Tables ................17 


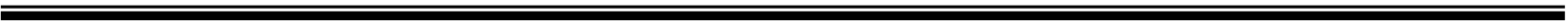

Assessment of Transit Information Materials and

Development of Criteria for Prototype Transit Materials

iv 


\section{INTRODUCTION}

For those who use transit on a daily basis, interpreting a transit route map or transit schedule may seem simple. However, occasional users or non-users may not find transit trip planning such an easy task. Besides the immediate issue of gaining access to transit information materials, the non-user or casual user may encounter significant difficulties in interpreting the transit route maps and transit schedules. While this is an issue for transit agencies throughout the country, Florida transit agencies are especially concerned about the effectiveness of transit information materials on the non-user's ability to plan a trip, as Florida is a major tourist destination.

Through a National Center for Transit Research project completed in 2001, several factors were identified as barriers to transit use. Operational Barriers and Impediments to Transit Use ${ }^{1}$, completed in December 2001, specifically identified the lack of effective and user-friendly bus schedules and route maps as a significant barrier to transit use among non-users. Through a field test designed to measure the effectiveness and clarity of printed transit information when presented to potential passengers with little to no previous transit use experience, the researchers found that design elements played an integral role in the trip planning process. Specifically, the quantitative and qualitative analyses conducted in the field test suggest that the use of certain design elements in printed transit materials resulted in higher transit trip planning scores and reduced levels of frustration and anxiety among field test participants (page 116). While the information gathered from the field test allowed the researchers to draw some generalizations about the effects of design element on the userfriendliness of transit information materials, definitive conclusions could not be made from the field test results. In particular, the field test was not organized such that individual design elements were isolated so that researchers could determine with some certainty which elements most affected the effectiveness and usefulness of the transit information materials.

\footnotetext{
${ }^{1}$ Hardin, Jennifer, Lisa Tucker, and Linda Callejas. Assessment of Operational Barriers and Impediments to Transit Use: Transit Information and Scheduling for Major Activity Centers. National Center for Transit Research at the Center for Urban Transportation Research, FDOT - 2001.
} 
In addition to the above findings, researchers associated with Operational Barriers and Impediments to Transit Use were encouraged to follow up the findings of the original report due to the overwhelming amount of feedback received from transit agency marketing representatives and transit consumers who were interested in the findings of the report as they related to transit information materials. Specifically, some who read the report or saw presentations on the findings encouraged the development of prototype or guidance materials for transit agencies to use based on the results of the study.

Encouraged by this support, as well as by support from the Florida Department of Transportation, NCTR plans to embark on a secondary project that will identify and test specific design elements to determine their significance in effective, usable transit information materials. Particularly, NCTR is interested in those design elements that improve the experience for first-time transit users. As a result, an intermediary project has been conducted to identify successful and user-friendly transit bus schedules and route maps and to classify each in terms of design elements. Another goal of this intermediate project was to develop and carry out a process for determining a sample of design elements to be included in the production and testing of transit information materials for the subsequent (secondary) project.

This report presents the results of the intermediate effort and outlines the course of the secondary project. The first section briefly details the various design elements that may be found in transit information materials and also describes the different ways those design elements might be displayed. The second section includes a database of transit bus schedules and route maps further classified by design elements. Section three describes the process by which the design elements that will be tested in the secondary project are selected. The final section of this report outlines the tasks associated with the follow-up project. 


\section{SECTION ONE Design Element Variations}

Design elements are thought to play a role in the effectiveness and userfriendliness of transit information materials. Although the degree to which design elements impact a non-user's ability to plan a trip on public transit is not known, evidence from the Operational Barriers to Transit Use project suggest that variations on design elements had some effect on the speed, ease, and accuracy at which participants in the field test were able to complete the trip planning process. An immediate issue facing a transit agency wishing to improve their transit schedules and maps is deciding which elements can affect the greatest improvement. Simply put, which design elements and which variations of those design elements make their material more user-friendly?

This section identifies many of the design elements that are featured in transit information materials and further describes how they might be varied. For most transit agencies, the selection of design element variations is not just a reflection of what works best for the transit consumer. Instead, the selection of design element variations is also dependent on other factors, such as number of routes, geographical layout of transit area boundaries, and financial resources. This identification of design element variations briefly addresses many of these factors.

\section{Material Format}

Generally, transit route schedules and maps are presented in system-wide guides, individual route pamphlets or brochures, or a combination of both. The sizes vary, as many are standard $81 / 2 \times 11$ sized sheets and others are significantly larger and are folded to a more manageable size. System-wide guides (or ride guides) tend to be in booklet form with several pages and generally include most, if not all, of the information that a passenger would need to ride the bus. 


\section{Front/Back Layout}

Another formatting characteristic of transit information materials is front/back layout. For individual route information, the schedule and route map are either presented on the same side of the page or on opposite sides of the page. Similarly, in ride guides it is typical for the route schedules and maps to either be on the same page or on adjacent pages in open booklet form.

\section{Font Size}

The font size used on transit information materials is usually a factor of how much information is being relayed and the amount of page space on which the information will be placed. Factors that should be considered when selecting font size are readability and audience. First, a font point that is too small may be difficult for a person with even average eyesight to read. This could lead to frustration on the part of the user and make the trip planning process more difficult. Another factor to consider is the audience. If a transit agency knows that its passenger base includes many elderly patrons or if they are attempting to attract more elderly patrons, it might consider using a font size that is more appropriate for elderly patrons, particularly those who might suffer from visual impairments such as cataracts.

\section{Stop Alignment}

Another format variation that can be seen among transit schedules is the stop alignment. A majority of transit schedules present time points or bus stops in horizontal form, or from left to right. However, there are some schedules that present time points in vertical form, or from top to bottom. Two factors for choosing to present the stops in vertical form over horizontal are size of the page on which the schedule is presented or number of stops. It can be extremely difficult to horizontally present a schedule that has a large number of stops on a standard size page (e.g. $81 / 2$ by 11 ). 


\section{Legend}

Legends are legitimate tools for map interpretation. However, many route and system maps do not include legends. Whether or not an agency utilizes a legend generally depends on what is being illustrated on the map. Many of the maps are very simplistic and the assumption is that a legend is not needed. If a route or system map identifies features such as transfer points, sheltered bus stops, points of interests, and road features, a legend may be quite useful. One of the most important inclusions in the legend of a system map is the route key. The route key provides a description, whether by color, name, or number, of the routes identified on the map.

\section{Use of Color (Aesthetic)}

There are typically three options related to the use of color for aesthetic effect. Transit materials are usually bi-color, multi-color, or black and white. The twocolor materials are usually black print on colored paper or colored print on white paper. The multi-color materials are generally a combination of colors - perhaps associating the schedule coloring with the colors of the buses, signs, and other system enhancements. Finally, some agencies utilize materials in black and white.

\section{Use of Color (Functional)}

The use of color as described above is different than using colors to represent routes. Use of color to represent routes is for functional effectiveness. Often transit agencies identify routes by color. A majority of the transit agencies in the database identify routes by colors. The biggest challenge in differentiating between routes by color on a map is selecting colors that are easily discernable and ensuring that the routes are not hidden under other routes traveling a similar path. There has also been considerable discussion about the ability of persons with visual impairments, including color blindness, to interpret maps when routes are differentiated by colors. There does not appear to be a consensus on the best way to identify routes on a system-wide map. 


\section{Time Scheduling}

Several participants in the original field test expressed confusion with the schedule timetable. Many cited that they were unsure what the times represented. Some asked if the times noted on the schedule were departure or arrival times. It is important for transit agencies to consider that understanding time points may not be inherent to first time transit users. Most transit information materials included in the database do not identify the time points on the schedule as departure or arrival times. Some of the transit agencies defined the time point in verbiage on the system map or within the ride guide.

Transit agencies also employ a variety of methods in differentiating between a.m. and p.m. service hours on schedules. Variations include labeling times as a.m. or p.m. and using bold type to identify p.m. service hours.

\section{Day Scheduling}

Many transit agencies that provide service on the weekends as well as weekdays offer a variation to weekday service on Saturday and/or Sunday. In these cases, it is important for transit agencies to relay the variations in the schedule to the transit customer. Generally, transit agencies have several options in achieving this. First, a transit agency may elect to denote weekend changes on the weekday schedule through use of symbols and footnotes. Another option is to have separate schedules for Saturday and Sunday. Identifying changes in the schedules with notations may be appropriate for minor changes such service hour modifications. However, when the weekend schedule is modified such that it loses resemblance to the weekday schedule, many transit agencies find it better to present the weekend schedule in another table.

In addition to summarizing the information above, Table 1 identifies other variations in design element that might impact a non-user's ability to plan and complete a transit trip. The table also offers testable variations and summarizes how the original Operational Barriers to Transit Use project showed how the design elements affected the trip planning ability of the participants in the field test (if known). 


\section{Table 1 - Design Element Variations}

\begin{tabular}{|c|c|c|}
\hline $\begin{array}{l}\text { Design Element } \\
\text { Variations }\end{array}$ & $\begin{array}{l}\text { How Can This } \\
\text { Element Be Tested? }\end{array}$ & $\begin{array}{c}\text { How Did the Original Barriers Project } \\
\text { Show That This Element Might } \\
\text { Affect the Trip Planning Ability of } \\
\text { Transit Non-Users? }\end{array}$ \\
\hline $\begin{array}{l}\text { Material Format } \\
\text { (Schedules and Maps) }\end{array}$ & $\begin{array}{l}\text { Variation 1: individual route } \\
\text { schedules/maps and a system map } \\
\text { Variation 2: ride guide with a } \\
\text { system map }\end{array}$ & $\begin{array}{l}\text { Participants reported higher task difficulty } \\
\text { for all-in-one ride guides than for } \\
\text { individual route schedules and a system- } \\
\text { wide map. However, there was significant } \\
\text { variation in scores between pilot and field } \\
\text { participants for both simple and complex } \\
\text { trips when comparing the ride guide and } \\
\text { individual route information elements. }\end{array}$ \\
\hline Material Format (Maps) & $\begin{array}{l}\text { (Schedule information the same for } \\
\text { each variation) } \\
\text { Variation 1: individual route map } \\
\text { Variation 2: system-wide map }\end{array}$ & $\begin{array}{l}\text { Participants reported difficulties with both } \\
\text { individual route maps and system-wide } \\
\text { maps. }\end{array}$ \\
\hline Front/Back Layout & $\begin{array}{l}\text { Variation 1: schedule and map on } \\
\text { same side of page } \\
\text { Variation 2: schedule and map on } \\
\text { opposite sides of page }\end{array}$ & $\begin{array}{l}\text { Comments were made with regards to } \\
\text { having to find the map associated with a } \\
\text { schedule or flipping back and forth. Many } \\
\text { cited preference for having both on same } \\
\text { sheet. }\end{array}$ \\
\hline Font Size & $\begin{array}{l}\text { Variation 1: small font (use point } \\
\text { size similar to one of smallest in } \\
\text { database) } \\
\text { Variation 2: larger font (use point } \\
\text { size similar to one of largest in } \\
\text { database) } \\
\text { This might also affect the size of } \\
\text { sheet (i.e. letter v. legal size } \\
\text { materials) }\end{array}$ & $\begin{array}{l}\text { While, some participants acknowledged } \\
\text { that smaller fonts posed some problem, it } \\
\text { was not determined from the results } \\
\text { whether it impacted the accuracy of their } \\
\text { trip planning or just the time at which it } \\
\text { took to finish the test. }\end{array}$ \\
\hline Stop Alignment & $\begin{array}{l}\text { Variation 1: stop alignment } \\
\text { presented horizontally (left to right) } \\
\text { Variation 2: stop alignment } \\
\text { presented vertically (top to bottom) }\end{array}$ & $\begin{array}{l}\text { This element was not necessarily } \\
\text { evaluated in the original project; however, } \\
\text { both variations are used by transit } \\
\text { agencies and there might be interest in } \\
\text { whether one is better than the other. }\end{array}$ \\
\hline Day Scheduling & $\begin{array}{l}\text { Variation 1: weekday and weekend } \\
\text { service shown in one table (uses } \\
\text { notations to identify differences in } \\
\text { service) } \\
\text { Variation } 2 \text { : weekday and weekend } \\
\text { service shown in separate tables }\end{array}$ & \\
\hline $\begin{array}{l}\text { Time Scheduling } \\
\text { (a.m./p.m. differentiation) }\end{array}$ & $\begin{array}{l}\text { Variation 1: differentiates between } \\
\text { a.m. and p.m. hours by labeling } \\
\text { them as such } \\
\text { Variation } 2 \text { : differentiates between } \\
\text { a.m. and p.m. hours through use of } \\
\text { bold type } \\
\text { Variation } 3 \text { : does not differentiate } \\
\text { between a.m. and p.m. hours }\end{array}$ & \\
\hline
\end{tabular}

Assessment of Transit Information Materials and

Development of Criteria for Prototype Transit Materials 


\begin{tabular}{|c|c|c|}
\hline $\begin{array}{l}\text { Design Element } \\
\text { Variations }\end{array}$ & $\begin{array}{l}\text { How Can This } \\
\text { Element Be Tested? }\end{array}$ & $\begin{array}{l}\text { How Did the Original Barriers Project } \\
\text { Show That This Element Might } \\
\text { Affect the Trip Planning Ability of } \\
\text { Transit Non-Users? }\end{array}$ \\
\hline $\begin{array}{l}\text { Time Scheduling } \\
\text { (Departure Time) }\end{array}$ & $\begin{array}{l}\text { Variation 1: Time points labeled as } \\
\text { "departure" } \\
\text { Variation 2: Time points not } \\
\text { labeled as departure or arrival }\end{array}$ & $\begin{array}{l}\text { Some of the participants said they did not } \\
\text { know if times were arrival or departure. } \\
\text { This could be a common issue for those } \\
\text { who are unfamiliar with using transit. }\end{array}$ \\
\hline Use of Color (Aesthetic) & $\begin{array}{l}\text { Variation 1: bi-color material } \\
\text { Variation 2: multi-color material } \\
\text { Variation 3: black and white } \\
\text { material }\end{array}$ & \\
\hline Map Details & $\begin{array}{l}\text { Variation 1: only time points and } \\
\text { related intersections are labeled on } \\
\text { map } \\
\text { Variation 2: Time points, related } \\
\text { intersections, and other streets are } \\
\text { labeled on map } \\
\text { Variation 3: Time points, related } \\
\text { intersections, other streets, points } \\
\text { of interest, and transfer points are } \\
\text { labeled }\end{array}$ & $\begin{array}{l}\text { Several participants described various } \\
\text { aspects of map detail, such as legends } \\
\text { and points of interest as helpful to the trip } \\
\text { planning process. }\end{array}$ \\
\hline Time Points Identified & $\begin{array}{l}\text { Variation 1: route displayed on map } \\
\text { with no time points identified } \\
\text { Variation 2: route displayed on map } \\
\text { with each time point on the map. }\end{array}$ & $\begin{array}{l}\text { Several respondents expressed difficulty } \\
\text { in identifying bus stops or time points on } \\
\text { the maps. }\end{array}$ \\
\hline Use of Color (Functional) & $\begin{array}{l}\text { Variation 1: identify routes by a } \\
\text { different colors on the system-wide } \\
\text { map } \\
\text { Variation 2: identify routes by a } \\
\text { means other than varied colors (i.e. } \\
\text { number) }\end{array}$ & \\
\hline Legend & $\begin{array}{l}\text { Variation 1: with legend } \\
\text { Variation 2: without legend }\end{array}$ & $\begin{array}{l}\text { Some participants cited legends with } \\
\text { clear, concise information as helpful. }\end{array}$ \\
\hline Transfer Points Identified & $\begin{array}{l}\text { Variation 1: transfer points are } \\
\text { identified on the system map } \\
\\
\text { Variation 2: transfer points are not } \\
\text { identified on the system map }\end{array}$ & $\begin{array}{l}\text { Some participants commented on the } \\
\text { difficulty associated with identifying actual } \\
\text { transfer points on the maps }\end{array}$ \\
\hline Directional Symbol & $\begin{array}{l}\text { Variation 1: north arrow facing up } \\
\text { Variation 2: north arrow facing } \\
\text { position other than up } \\
\text { Variation 3: no directional symbol } \\
\text { on map }\end{array}$ & $\begin{array}{l}\text { The impact of this particular design } \\
\text { element may not be adequately reflected } \\
\text { through a field test. Ideally, the } \\
\text { participants will be unfamiliar with the } \\
\text { testing area and are transit non-users so } \\
\text { knowing directional details may not be as } \\
\text { useful as to someone who knows the } \\
\text { area. }\end{array}$ \\
\hline
\end{tabular}

Assessment of Transit Information Materials and

Development of Criteria for Prototype Transit Materials 


\section{SECTION TWO \\ Transit Information Materials Database}

The original project involved collecting transit bus schedules and route and system maps from transit agencies throughout Florida and other states. That effort resulted in the collection of schedules and maps from 23 systems in Florida and over 15 systems in other states. The intermediate project required that additional materials be collected from other agencies to ensure that an array of design elements were catalogued and compared. This allowed the researchers to adequately assess the relevance of design elements. Table 2 identifies all of the transit agencies for which transit schedules or maps were collected. In all, 17 individual route schedules and 16 system or multi-route ride guides were entered into the database. These transit information materials represented 34 transit agencies. Tables 3 through 10 identify the various design elements for the transit information materials listed in the database.

Along with identifying the transit agencies from which transit information was collected, Table 2 also categorizes the transit information by format. Format options are individual route schedules and maps with a system-wide map (14 documents fit in this category); individual route schedules and maps with no system map (three documents fit in this category); all or most routes depicted in a ride guide that includes a system-wide map (15 documents fit in this category); and all or most routes depicted in a ride guide that does not include a systemwide map (none of the documents in the database fit in this category). In addition to the agencies using these formats, five agencies utilize both the "ride guide" and individual route schedules and maps. Also, one agency divides its routes into geographical areas and has several "multi-route" guides. These guides contain schedules and maps for several routes, rather than one systemwide ride guide or individual route guides.

The format of choice appears to be fairly evenly split between individual route guides and system-wide ride guides, which suggests that there is no clear consensus on whether one method is better than another. Figure 1 illustrates how individual route schedules and maps are presented by a transit system. Figure 2 shows an all-in-one ride guide. 
Table 2 -- Transit Schedule/Map Inventory: Information Format

\begin{tabular}{|c|c|c|c|c|c|c|c|}
\hline \multirow[b]{2}{*}{ Transit System } & \multirow[b]{2}{*}{ Location } & \multirow[b]{2}{*}{ Type } & \multicolumn{5}{|c|}{ System/Route Information Format } \\
\hline & & & $\begin{array}{c}\text { Individual } \\
\text { Route } \\
\text { Schedules/ } \\
\text { Maps w/ } \\
\text { System Map }\end{array}$ & \begin{tabular}{|c|} 
Individual \\
Route \\
Schedules/ \\
Maps - no \\
System Map
\end{tabular} & \begin{tabular}{|c|} 
All Routes \\
in Ride \\
Guide-- \\
includes \\
System Map
\end{tabular} & $\begin{array}{l}\text { All Routes } \\
\text { in Ride } \\
\text { Guide -- no } \\
\text { System Map }\end{array}$ & $\begin{array}{c}\text { Indiv. Rte. } \\
\text { Schedules/ } \\
\text { Maps and } \\
\text { Ride Guide } \\
\text { with System } \\
\text { Map }\end{array}$ \\
\hline AppalCART & Boone, NC & Complete System Map-8/02 & & & $\mathrm{x}$ & & \\
\hline AT & Vermont & Ride Guide-10/02 & & & $\mathrm{x}$ & & \\
\hline Bay Town Trolley & Panama City & Ride Guide-9/00 & & & $\mathrm{x}$ & & \\
\hline BCT & Broward & Individual Route Sch/Map-8/00 & $\mathrm{X}$ & & & & \\
\hline CAT & Las Vegas & Ride Guide-9/02 & & & $\mathrm{x}$ & & \\
\hline C-UMTD & Champaign, IL & Ride Guide-8/02 & & & $\mathrm{x}$ & & \\
\hline CYRide & Des Moines & Complete System Map-8/02 & & & $\mathrm{x}$ & & \\
\hline DART & Dallas & Individual Rte Sch/Map-5/02 & $\mathrm{x}$ & & & & \\
\hline DTA & Daluth, MN & Individual Rte Sch/Maps-5/02 & & $\mathrm{X}$ & & & \\
\hline ECAT & Escambia & Ride Guide-11/01 & & & $\mathrm{x}$ & & \\
\hline GFT & Great Falls, MT & Ride Guide-9/02 & & & $\mathrm{x}$ & & \\
\hline HARTline & Hillsborough & Individual Route Sch/Map-5/01 & $\mathrm{X}$ & & & & \\
\hline IndyGo & Indianopolis & Individual Rte Sch/Maps-11/88 & $\mathrm{X}$ & & & & \\
\hline JTA & Jacksonville & Individual Route Sch/Map-7/99 & $\mathrm{x}$ & & & & \\
\hline Key West & Key West & Bus Schedule & & & $\mathrm{x}$ & & \\
\hline LAMT & Lakeland & Individual Rte Sch/Map-10/00 & & $\mathrm{x}$ & & & \\
\hline LeeTran & Lee County & Individual Rte Sch/Map-9/00 & $\mathrm{X}$ & & & & \\
\hline LYNX & Orlando area & Schedule Book-5/01 & & & & & $\mathrm{x}$ \\
\hline LYNX & Orlando area & Indivdual Rte Sch/Map-12/99 & & & & & $\mathrm{x}$ \\
\hline MBTA & Boston & Individual Rte Sch/Maps-8/02 & $\mathrm{X}$ & & & & \\
\hline MCAT & Manatee & Ride Guide-1/01 & & & $\mathrm{x}$ & & \\
\hline MDT & Miami-Dade & Individual Rte Sch/Map-4/01 & $\mathrm{x}$ & & & & \\
\hline MVTA & Burnsville, MN & Individual Rte Sch/Map-6/02 & $\mathrm{x}$ & $\mathrm{x}$ & & & \\
\hline OCT & Okaloosa & Ride Guide -- FWB Wave only & $\mathrm{X}$ & & & & \\
\hline Palm Tran & Palm Beach & Individual Rte Sch/Map-10/00 & & & & & $\mathrm{x}$ \\
\hline PalmTran & Palm Beach & System Map-10/00 & & & & & $\mathrm{x}$ \\
\hline PCPT & Pasco & Individual Rte Sch/Map-1/00 & $\mathrm{X}$ & & & & \\
\hline PSTA & Pinellas & Individual Rte Sch/Map-12/00 & $\mathrm{X}$ & & & & \\
\hline RTS & Gainesville & Ride Guide-1/01 & & & $\mathrm{x}$ & & \\
\hline SCAT & Sarasota & Ride Guide-Spring 2000 & & & $\mathrm{x}$ & & \\
\hline SCAT & Brevard & Ride Guide-6/00 & & & $\mathrm{x}$ & & \\
\hline SunTran & Ocala & System Route and Map-11/99 & & & $\mathrm{x}$ & & \\
\hline TalTran & Tallahassee & Ride Guide-8/00 & & & $\mathrm{X}$ & & \\
\hline TARC & Louisville, KY & Individual Rte Sch/Map-5/02 & $\mathrm{x}$ & & & & \\
\hline VOTRAN & Volusia & Area Rte Sch/Maps-1/00 & & & Some & & \\
\hline WHAT & Winter Haven & Individual Rte Sch/Map-2/00 & $x$ & & & & \\
\hline
\end{tabular}

* VOTRAN divides its service area into geographical sections and utilizes multi-route guides for each of those geographical sections.

Assessment of Transit Information Materials and

Development of Criteria for Prototype Transit Materials 


\section{Figure 1}

\section{Individual Route Schedule and Map}

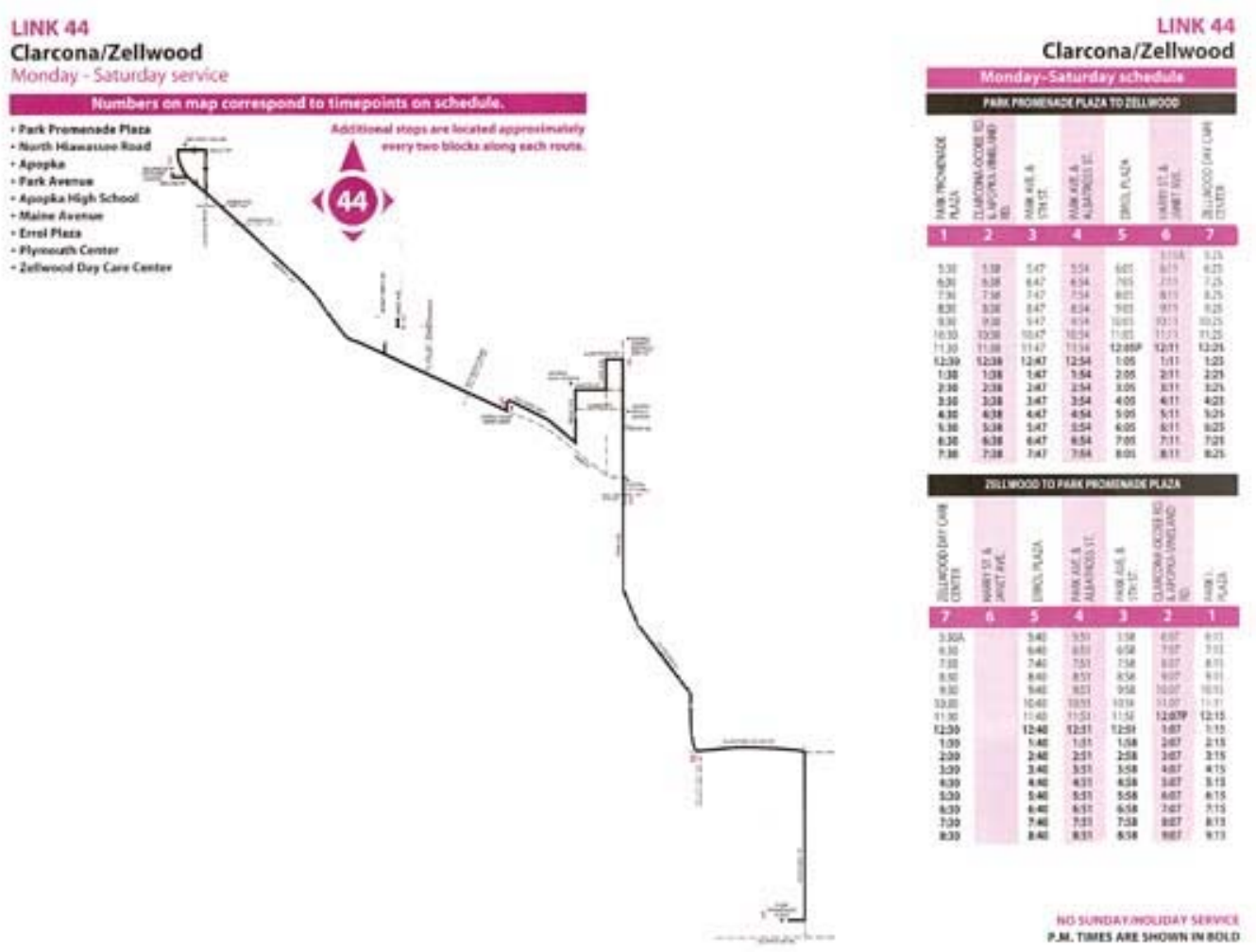


Figure 2

All-In-One Route Guide

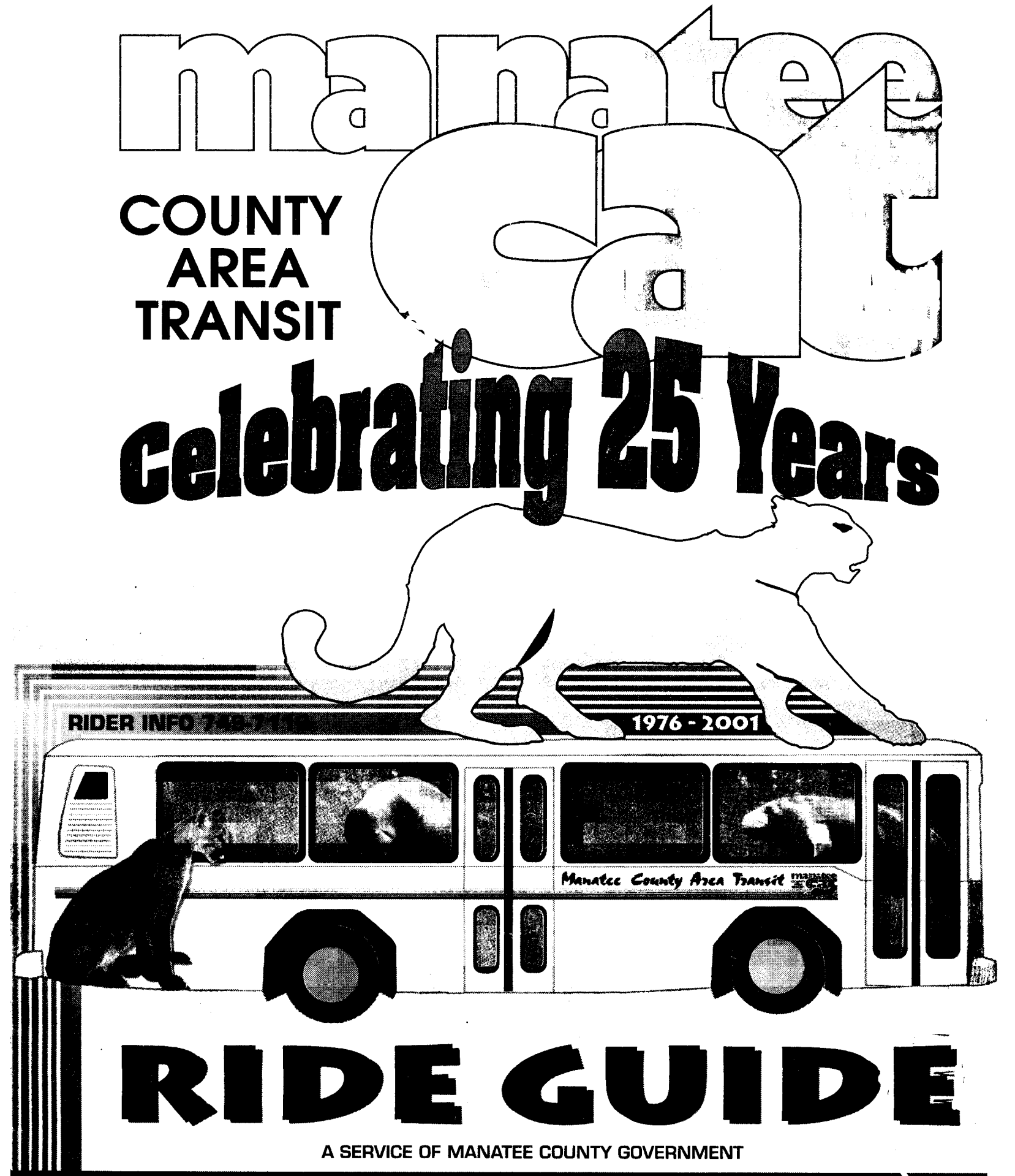

Monday through Saturday Service Plus Tripper Service Mon. through Fri. EFFECTIVE JANUARY 22, 2001 
In Table 3, the presentation of the information is further compared. Specifically, this table identifies whether the route schedule and route map are visible without switching or turning pages. For instance, on individual route transit information, the schedule and map may be on opposite sides or may be positioned adjacent to one another on the same side of the page. In route guides that have individual maps in addition to individual schedules, they are generally positioned on the same page or the adjacent page (if in book form). However, in several instances, there was one map for all of the individual routes and that map was on a different page (if in book form) or on the opposite side of the route guide (if in fold-out pamphlet form). Examples of these formats are shown in Figures 3 and 4.

Figure 3

Map and Schedule on Same Page

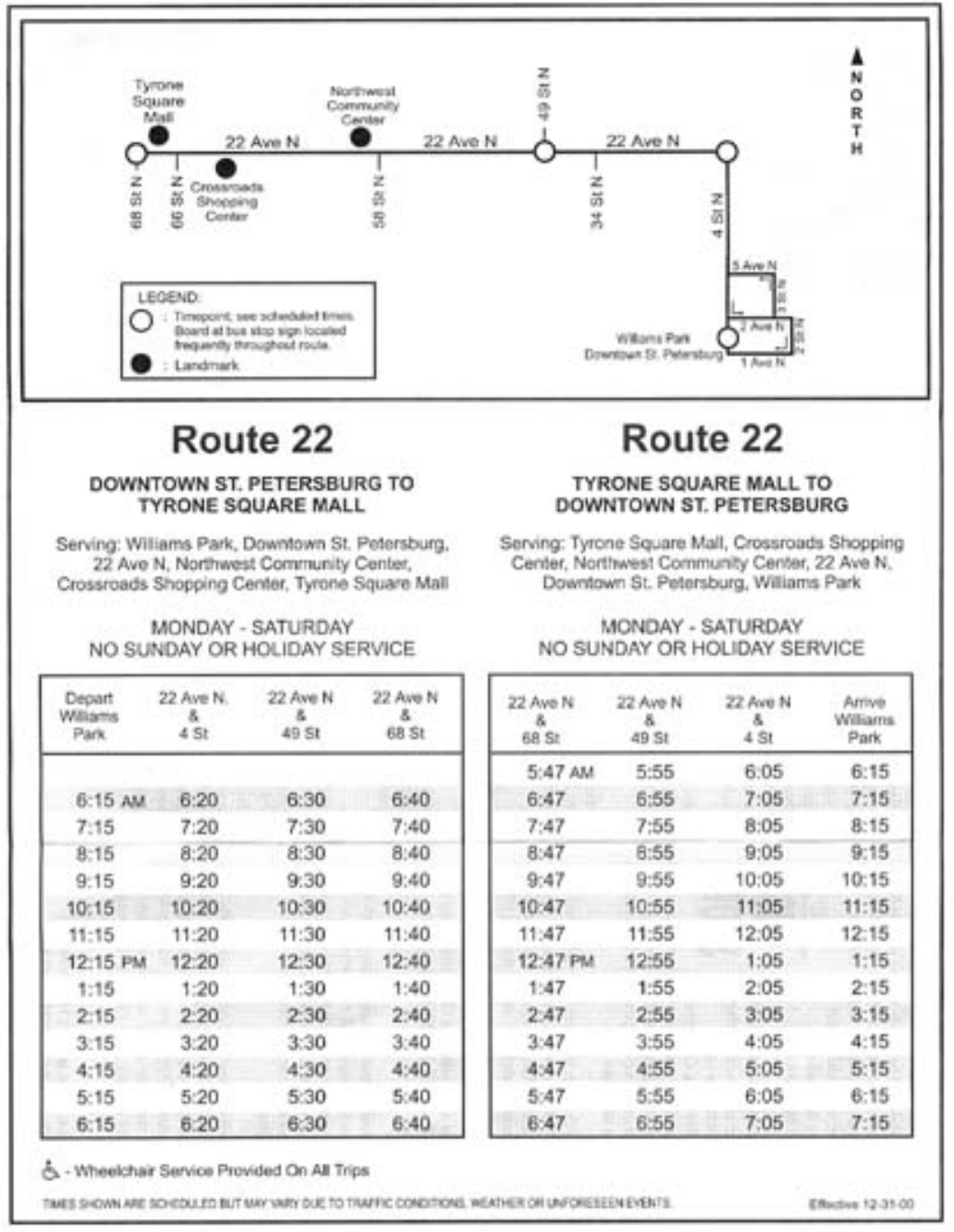

Assessment of Transit Information Materials and

Development of Criteria for Prototype Transit Materials 
Figures $4 a$ and $4 b$

Map and Schedule on Front and Back of Transit Material

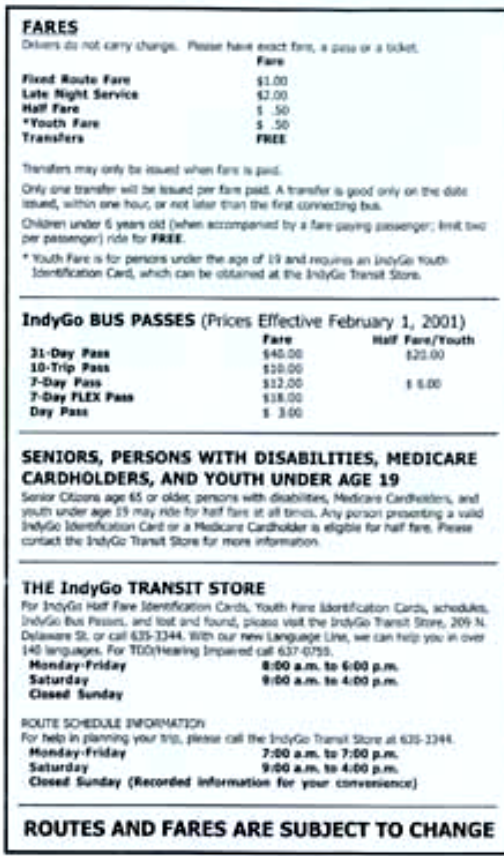

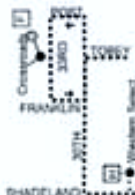

星

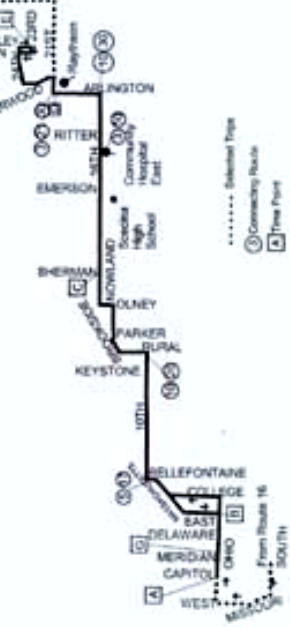

11

East 16th Street Enective May 12, 2002
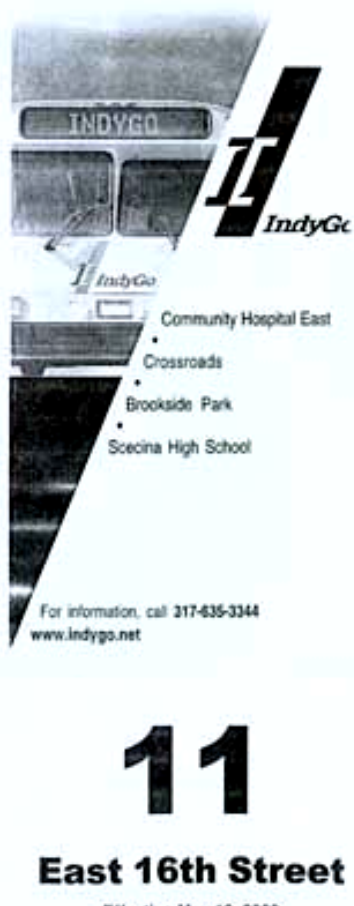

Enective May 12, 2002

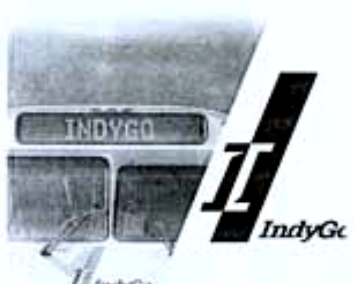

If mabas

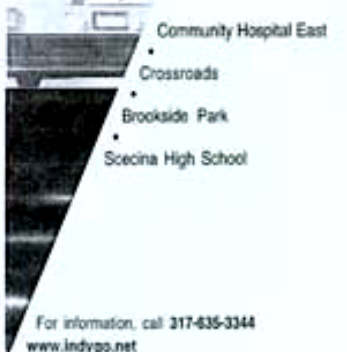

Assessment of Transit Information Materials and

Development of Criteria for Prototype Transit Materials 


\section{Table 3-- Transit Schedule/Map Inventory: Information Format (Front/Back Layout)}

\begin{tabular}{|c|c|c|c|c|c|c|}
\hline \multirow[b]{2}{*}{ Transit System } & \multirow[b]{2}{*}{ Location } & \multirow[b]{2}{*}{ Type } & \multicolumn{4}{|c|}{ Back/Front Layout } \\
\hline & & & $\begin{array}{c}\text { Indiv: } \\
\text { Schedule } \\
\text { and Map on } \\
\text { same side of } \\
\text { page }\end{array}$ & $\begin{array}{c}\text { Indiv: } \\
\text { Schedule and } \\
\text { Map on } \\
\text { opposite side } \\
\text { of page }\end{array}$ & $\begin{array}{c}\text { Ride Guide: } \\
\text { Schedule and } \\
\text { Map on } \\
\text { adjacent page } \\
\text { or same page }\end{array}$ & $\begin{array}{l}\text { Ride Guide: } \\
\text { Schedule and } \\
\text { Map on } \\
\text { different or } \\
\text { opposite page }\end{array}$ \\
\hline $\mathrm{BCT}$ & Broward & Individual Rte Sch/Map-8/00 & & $x$ & & \\
\hline DART & Dallas & Individual Rte Sch/Map-5/02 & $x$ & & & \\
\hline DTA & Daluth, MN & Individual Rte Sch/Maps-5/02 & & $\mathrm{x}$ & & \\
\hline HARTline & Hillsborough & Individual Rte Sch/Map-5/01 & & $\mathrm{x}$ & & \\
\hline IndyGo & Indianapolis & Individual Rte Sch/Maps-11/88 & & $\mathrm{X}$ & & \\
\hline JTA & Jacksonville & Individual Route Sch/Map-7/99 & & $x$ & & \\
\hline LAMT & Lakeland & Individual Rte Sch/Map-10/00 & $x$ & & & \\
\hline LeeTran & Lee County & Individual Rte Sch/Map-9/00 & $\mathrm{x}$ & & & \\
\hline LYNX & Orlando area & Schedule Book-5/01 & $x$ & & & \\
\hline MBTA & Boston & Individual Rte Sch/Maps-8/02 & & $x$ & & \\
\hline MDT & Miami-Dade & Individual Rte Sch/Map-4/01 & $\mathrm{x}$ & & & \\
\hline MVTA & Burnsville, MN & Individual Rte Sch/Map-6/02 & $\mathrm{x}$ & & & \\
\hline Palm Tran & Palm Beach & Individual Rte Sch/Map-10/00 & $\mathrm{x}$ & & & \\
\hline PCPT & Pasco & Individual Rte Sch/Map-1/00 & $\mathrm{x}$ & & & \\
\hline PSTA & Pinellas & Individual Rte Sch/Map-12/00 & $\mathrm{x}$ & & & \\
\hline TARC & Louisville, KY & Individual Rte Sch/Map-5/02 & $x$ & & & \\
\hline WHAT & Winter Haven & Individual Rte Sch/Map-2/00 & $x$ & & & \\
\hline AppalCART & Boone, NC & Complete System Map-8/02 & & & & $x$ \\
\hline AT & Vermont & Ride Guide-10/02 & & & $\mathrm{x}$ & \\
\hline Bay Town Trolley & Panama City & Ride Guide-9/00 & & & $x$ & \\
\hline CAT & Las Vegas & Ride Guide-9/02 & & & $x$ & \\
\hline C-UMTD & Champaign, IL & Ride Guide-8/02 & & & $x$ & \\
\hline CYRide & Des Moines & Complete System Map-8/02 & & & & $\mathrm{x}$ \\
\hline ECAT & Escambia & Ride Guide-11/01 & & & $x$ & \\
\hline GFT & Great Falls, MT & Ride Guide-9/02 & & & & $x$ \\
\hline Key West & Key West & Bus Schedule & & & $x$ & \\
\hline LYNX & Orlando area & Individual Rte Sch/Map-12/99 & & & $\mathrm{x}$ & \\
\hline MCAT & Manatee & Ride Guide-1/01 & & & $x$ & \\
\hline OCT & Okaloosa & Ride Guide-FWB Wave only & & & & $x$ \\
\hline PalmTran & Palm Beach & Riders Guide-10/00 & & & $\mathrm{x}$ & \\
\hline RTS & Gainesville & Ride Guide-1/01 & & & $x$ & \\
\hline SCAT & Sarasota & Ride Guide-Spring 2000 & & & & $x$ \\
\hline SCAT & Brevard & Ride Guide-6/00 & & & $x$ & \\
\hline SunTran & Ocala & System Route and Map-11/99 & & & & $\mathrm{x}$ \\
\hline TalTran & Tallahassee & Ride Guide-8/00 & & & $x$ & \\
\hline VOTRAN & Volusia & Area Rte Sch/Maps-1/00 & & & & $\mathrm{X}$ \\
\hline
\end{tabular}


Table 4 compares the time and day scheduling format presented in the transit information materials for Florida systems. Obviously, the manner in which day scheduling is presented is partly a factor of whether or not weekend and holiday service is provided by the agency. When comparing the written schedules of the transit agencies, the main difference in the way that time scheduling was presented was related to differentiating between a.m. and p.m. service hours. According to Table 4, none of the materials collected presented a.m. and p.m. service hours in separate tables. Ten of the schedules and ride guides labeled a.m. and p.m. service hours as such (see Figure 5) and five of them bolded p.m. service hours to differentiate from a.m. service hours (see Figure 6). Seven of the materials collected for this study did not differentiate between a.m. and p.m. service hours on the schedule.

Figure 5

\section{A.M. and P.M. Hours Labeled}

\section{EAST: TO ROSEMOUNT}

\begin{tabular}{ccccc} 
& $\begin{array}{c}\text { Apple } \\
\text { Valley } \\
\text { Transit } \\
\text { Station }\end{array}$ & $\begin{array}{c}\text { 147th St } \\
\& \\
\text { Galaxie } \\
\text { Library }\end{array}$ & $\begin{array}{c}\text { Diamond } \\
\text { Path }\end{array}$ & $\begin{array}{c}\text { Rosemount } \\
\text { Plaza }\end{array}$ \\
\hline & AM & AM & AM & AM \\
\hline $\mathbf{4 2 0}$ & 601 & $\cdot$ & 616 & 631 \\
\hline $\mathbf{4 2 0}$ & 631 & $\cdot$ & 646 & 701 \\
\hline $\mathbf{4 2 0}$ & 731 & 741 & 751 & 801 \\
\hline $\mathbf{4 2 0}$ & 855 & 905 & 915 & 925 \\
\hline & PM & PM & PM & PM \\
\hline $\mathbf{4 2 0}$ & 255 & 305 & 315 & 325 \\
\hline $\mathbf{4 2 0}$ & $400 \mathrm{x}$ & 410 & 420 & 430 \\
\hline $\mathbf{4 2 0}$ & $500 \mathrm{x}$ & $\cdot$ & 515 & 530 \\
\hline $\mathbf{4 2 0}$ & $530 \mathrm{x}$ & $\cdot$ & 545 & 600 \\
\hline $\mathbf{4 2 0}$ & $600 \mathrm{x}$ & $\cdot$ & 615 & 630 \\
\hline $\mathbf{4 2 0}$ & $630 \mathrm{x}$ & $\cdot$ & 645 & 700 \\
\hline
\end{tabular}

-Bus stops at this location by reservation only on these trips.

$x$ Conaect from Route 477 from Downtowa Mianeapolis

\section{WEST: TO APPLE VALLEY}

\begin{tabular}{ccccc}
\hline $\begin{array}{c}\text { Rosemount } \\
\text { Plaza }\end{array}$ & $\begin{array}{c}\text { 147th St } \\
\text { \& } \\
\text { Diamond } \\
\text { Path }\end{array}$ & $\begin{array}{c}\text { Apple } \\
\text { Galaxie } \\
\text { Library }\end{array}$ & $\begin{array}{c}\text { Valley } \\
\text { Transit } \\
\text { Slation }\end{array}$ \\
\hline 420 & 531 & AM & AM & AM \\
\hline 420 & 601 & 616 & $\cdot$ & $601 x$ \\
\hline 420 & 631 & 646 & $\cdot$ & $631 x$ \\
\hline 420 & 701 & 716 & $\cdot$ & $701 \mathrm{x}$ \\
\hline 420 & 825 & 835 & 845 & 855 \\
\hline 4 & PM & PM & PM & PM \\
\hline 420 & 225 & 235 & 245 & 255 \\
\hline 420 & 325 & 335 & 345 & 355 \\
\hline 420 & 430 & 440 & 450 & 500 \\
\hline 420 & 530 & 540 & 550 & 600 \\
\hline 420 & 600 & 610 & 620 & 630 \\
\hline
\end{tabular}

-Bus stops at this location by reservation only on these trips. $x$ Conaect to Route 477 to Downtown Mianeapolis 
Figure 6

\section{P.M. Service Hours in Bold}

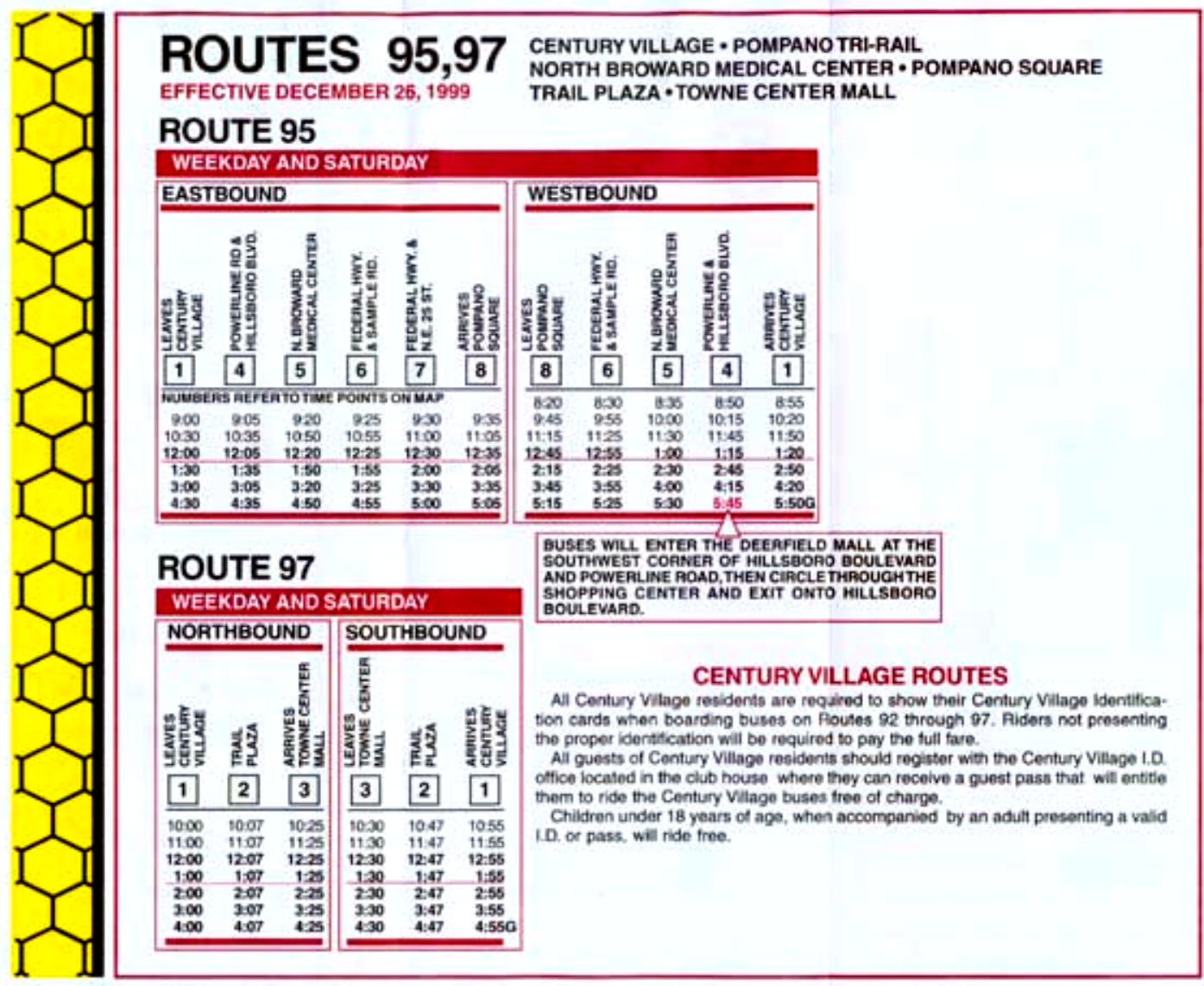

Table 4 also demonstrates how transit agencies depict day scheduling in their transit information materials. It is important to note that for each transit agency, the day scheduling for individual routes may vary. For instance, one route may operate on weekdays only, while another operates on weekdays and Saturday. In such cases, Table 4 depicts the scheduling format used for the route that provides service on weekdays and Saturday. The purpose of the information in this table is to show how varied schedules are depicted in transit information materials. According to Table 4, only two of the transit information materials in the database have weekday only transit schedules. Consequently, these materials come from agencies that have weekday only service. Thirteen of the transit information materials show weekdays and Saturday service in the same table. An example of this format is shown in Figure 7. Two show weekday and Saturday service in separate tables (see Figure 8) and six show weekday, 
Saturday, and Sunday service in three separate tables. The transit information material for one agency did not identify on the schedule which days transit service is provided.

\section{Figure 7}

\section{Weekday and Saturday Service Shown in Same Table (Weekday-Only Service Shaded)}

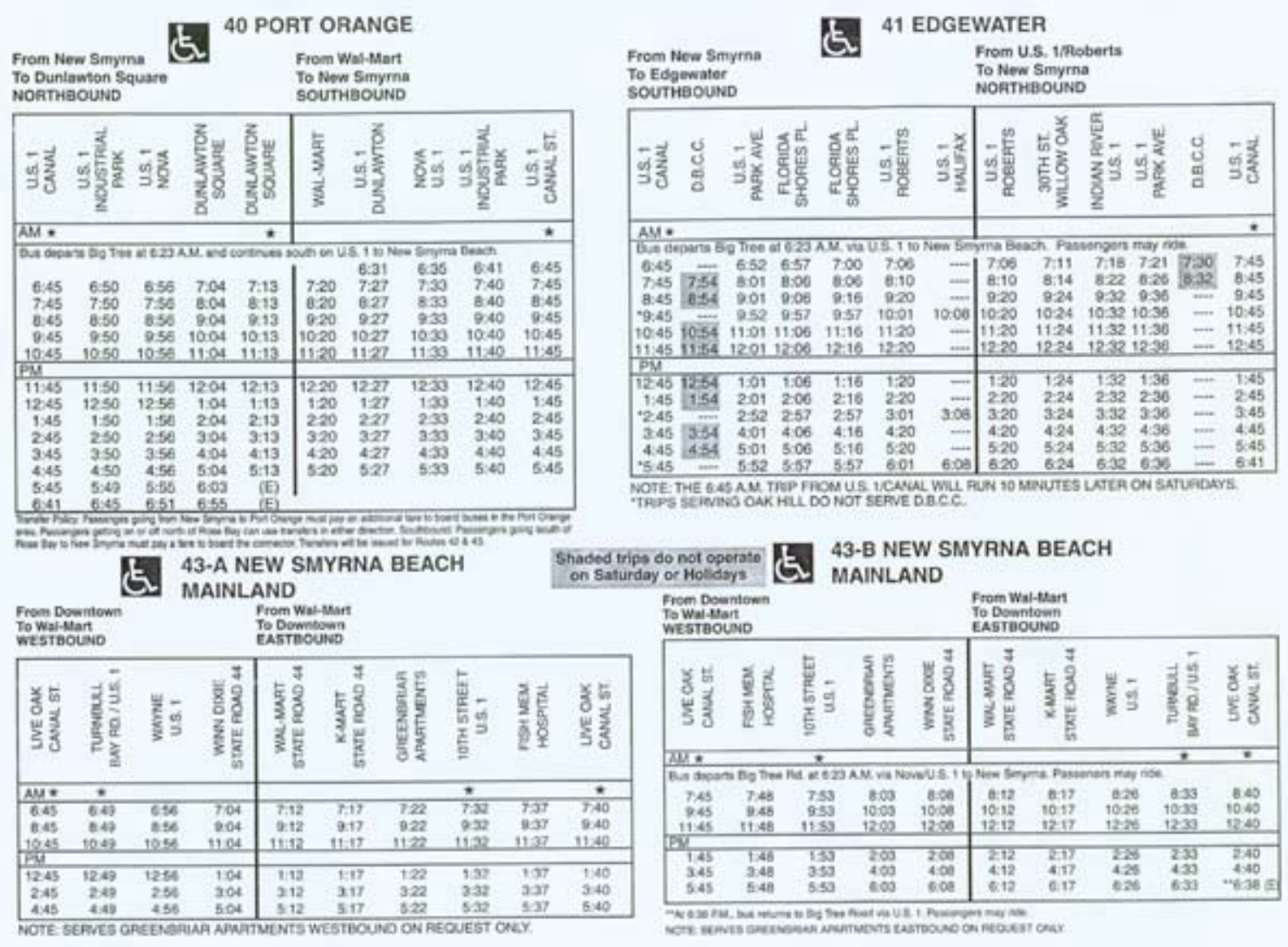


Figure 8

Weekday and Saturday Service Shown in Separate Tables

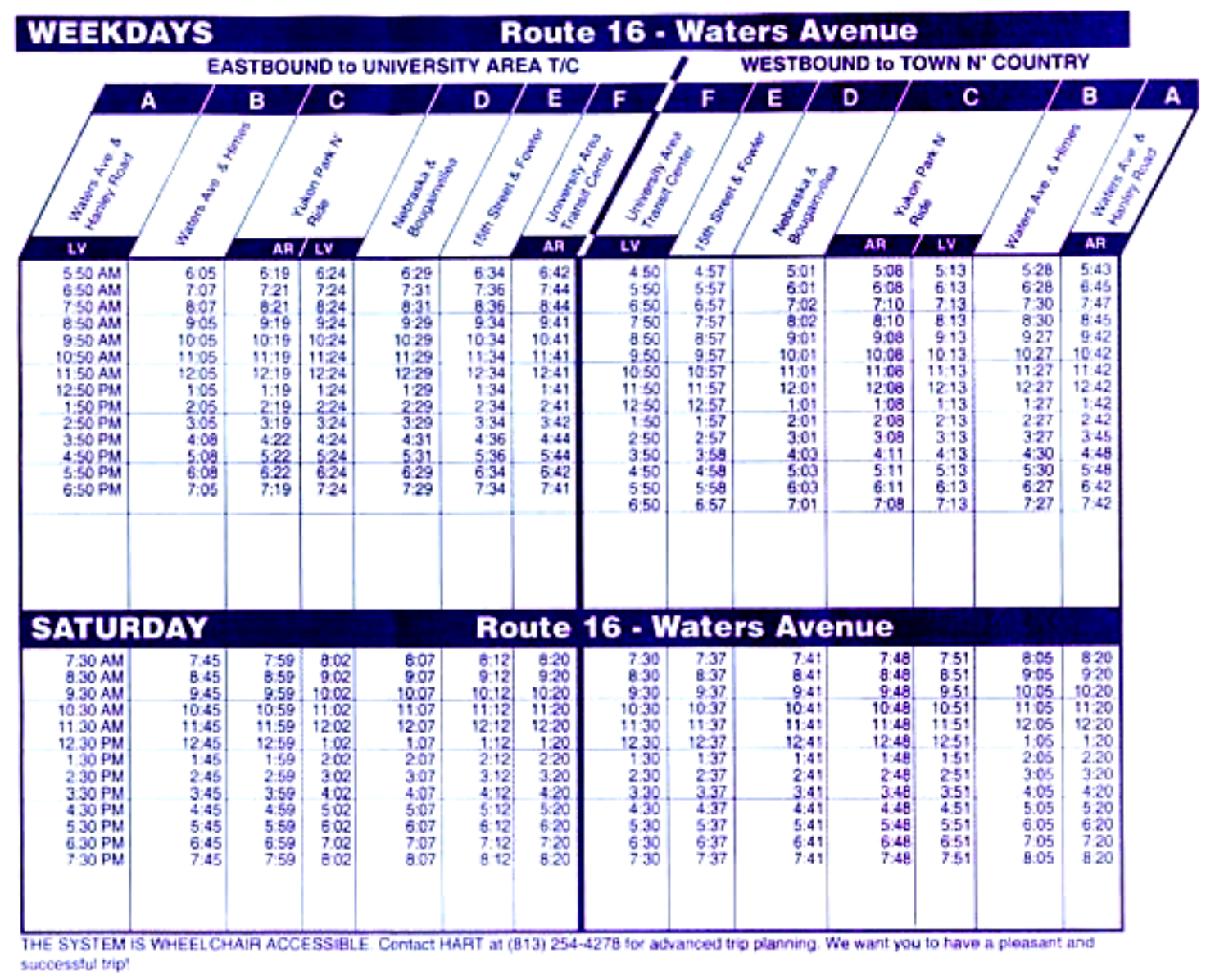

Assessment of Transit Information Materials and

Development of Criteria for Prototype Transit Materials 
Table 4 -- Transit Schedule/Map Inventory: Time and Day Scheduling (Florida Systems)

\begin{tabular}{|c|c|c|c|c|c|c|c|c|c|c|c|}
\hline \multirow[b]{2}{*}{ Transit System } & \multirow[b]{2}{*}{ Location } & \multirow[b]{2}{*}{ Type } & \multicolumn{4}{|c|}{ Time } & \multicolumn{5}{|c|}{ Day Scheduling } \\
\hline & & & $\begin{array}{c}\text { a.m./p.m.- } \\
\text { separate } \\
\text { tables }\end{array}$ & $\begin{array}{c}\text { a.m./p.m.- } \\
\text { labeled as } \\
\text { such }\end{array}$ & \begin{tabular}{|c|} 
Bold type \\
indicates \\
p.m. hours
\end{tabular} & $\begin{array}{c}\text { a.m./p.m. } \\
\text { not } \\
\text { different- } \\
\text { iated }\end{array}$ & $\begin{array}{c}\text { Weekdays } \\
\text { only }\end{array}$ & $\begin{array}{c}\text { Weekdays \& } \\
\text { Saturdays -- } \\
\text { same table }\end{array}$ & $\begin{array}{c}\text { Weekdays \& } \\
\text { Saturdays -- } \\
\text { separate } \\
\text { tables }\end{array}$ & $\begin{array}{c}\text { Weekdays } \\
\text { \& weekend } \\
\text { (Saturday \& } \\
\text { Sunday) } \\
\text { separate } \\
\text { tables }\end{array}$ & $\begin{array}{l}\text { Weekdays, } \\
\text { Saturday, \& } \\
\text { Sunday -- } \\
\text { Separate (3) } \\
\text { tables }\end{array}$ \\
\hline Bay Town Trolley & Panama City & Ride Guide-9/5/00 & & & & & $\mathrm{X}$ & & & & \\
\hline $\mathrm{BCT}$ & Broward & Individual Route Sch/Map-8/00 & & & $\mathrm{x}$ & & & & & & $\mathrm{x}$ \\
\hline ECAT & Escambia & Ride Guide-11/01 & & & & $\mathrm{x}$ & & & $\mathrm{X}$ & & \\
\hline HARTline & Hillsborough & Individual Route Sch/Map-5/01 & & $\mathrm{x}$ & & & & & & & $\mathrm{x}$ \\
\hline JTA & Jacksonville & Individual Route Sch/Map-7/99 & & & $\mathrm{X}$ & & & & $\mathrm{X}$ & & \\
\hline Key West & Key West & Bus Schedule & & $\mathrm{X}$ & & & & $\mathrm{X}$ & & & \\
\hline LAMT & Lakeland & Individual Rte Sch/Map-10/00 & & & & $\mathrm{X}$ & & $\mathrm{X}$ & & & \\
\hline LeeTran & Lee County & Individual Rte Sch/Map-9/00 & & & & $\mathrm{x}$ & & $\mathrm{x}$ & & & \\
\hline LYNX & Orlando area & Schedule Book-5/01 & & & $\mathrm{x}$ & & & $\mathrm{x}$ & & & \\
\hline LYNX & Orlando area & Indivdual Rte Sch/Map-12/99 & & & $\mathrm{x}$ & & & $\mathrm{x}$ & & & \\
\hline MCAT & Manatee & Ride Guide-1/01 & & & & $\mathrm{X}$ & & $\mathrm{X}$ & & & \\
\hline MDT & Miami-Dade & Individual Rte Sch/Map-4/01 & & $\mathrm{x}$ & & & & & & & $\mathrm{X}$ \\
\hline OCT & Okaloosa & Ride Guide-FWB Wave only & & & & $\mathrm{x}$ & \multicolumn{5}{|c|}{ * does not specify } \\
\hline Palm Tran & Palm Beach & Individual Rte Sch/Map-10/00 & & $\mathrm{x}$ & & & & & & & $\mathrm{x}$ \\
\hline PalmTran & Palm Beach & Riders Guide-10/00 & & $\mathrm{x}$ & & & & & & & $\mathrm{x}$ \\
\hline PCPT & Pasco & Individual Rte Sch/Map-1/00 & & & & $\mathrm{X}$ & $\mathrm{X}$ & & & & \\
\hline PSTA & Pinellas & Individual Rte Sch/Map-12/00 & & $\mathrm{x}$ & & & & $\mathrm{x}$ & & & \\
\hline RTS & Gainesville & Ride Guide-1/01 & & $\mathrm{X}$ & & & & $\mathrm{X}$ & & & \\
\hline SCAT & Sarasota & Ride Guide-Spring 2000 & & $\mathrm{x}$ & & & & $\mathrm{X}$ & & & \\
\hline SCAT & Brevard & Ride Guide-6/00 & & & & & & & & & $\mathrm{x}$ \\
\hline SunTran & Ocala & System Route and Map-11/99 & & $\mathrm{X}$ & $\mathrm{x}$ & & & $\mathrm{x}$ & & & \\
\hline TalTran & Tallahassee & Ride Guide- $8 / 00$ & & & $\mathrm{x}$ & & & $\mathrm{x}$ & & & \\
\hline VOTRAN & Volusia & Area Rte Sch/Maps-1/00 & & $\mathrm{x}$ & & & & $\mathrm{x}$ & & & \\
\hline WHAT & Winter Haven & Individual Rte Sch/Map-2/00 & & & & $\mathrm{x}$ & & $\mathrm{x}$ & & & \\
\hline
\end{tabular}


Table 5 presents the identical information as Table 4, except on transit information materials from non-Florida transit agencies. According to Table 5, none of the transit information materials from non-Florida transit agencies have separate tables for a.m. and p.m. service hours, three of the agencies label the times in their schedules as a.m. or p.m., five use bold type to indicate p.m. service hours, and two of the schedules do not differentiate between a.m. and p.m. service hours. Table 5 also demonstrates that two of the schedules depict weekday service only (the corresponding agencies only provide weekday service). Of the remaining agencies (10), weekday and some weekend service are provided. For those agencies, six present weekday and Saturday service hours in separate tables; two present weekdays and weekend (Saturday and Sunday) service hours in separate tables; and two present weekday, Saturday, and Sunday in three separate tables. 
Table 5-- Transit Schedule/Map Inventory: Time and Day Scheduling (Non-Florida Systems)

\begin{tabular}{|c|c|c|c|c|c|c|c|c|c|c|c|}
\hline \multirow[b]{2}{*}{$\begin{array}{l}\text { Transit } \\
\text { System }\end{array}$} & \multirow[b]{2}{*}{ Location } & \multirow[b]{2}{*}{ Type } & \multicolumn{4}{|c|}{ Time } & \multicolumn{5}{|c|}{ Day Scheduling } \\
\hline & & & $\begin{array}{l}\text { a.m./p.m.- } \\
\text { separate } \\
\text { tables }\end{array}$ & $\begin{array}{c}\text { a.m./p.m.- } \\
\text { labeled as } \\
\text { such }\end{array}$ & $\begin{array}{c}\text { Bold type } \\
\text { indicates } \\
\text { p.m. } \\
\text { hours }\end{array}$ & $\begin{array}{c}\text { a.m./p.m. } \\
\text { not } \\
\text { different- } \\
\text { iated }\end{array}$ & $\begin{array}{c}\text { Weekdays } \\
\text { only }\end{array}$ & \begin{tabular}{|c|} 
Weekdays \\
$\&$ \\
Saturdays -- \\
same table
\end{tabular} & $\begin{array}{c}\text { Weekdays \& } \\
\text { Saturdays -- } \\
\text { separate } \\
\text { tables }\end{array}$ & $\begin{array}{c}\text { Weekdays \& } \\
\text { weekend } \\
\text { (Saturday \& } \\
\text { Sunday) } \\
\text { separate } \\
\text { tables }\end{array}$ & $\begin{array}{l}\text { Weekdays, } \\
\text { Saturday, \& } \\
\text { Sunday -- } \\
\text { Separate (3) } \\
\text { tables }\end{array}$ \\
\hline AppalCART & Boone, NC & Complete System Map-8/02 & & & & & $x$ & & & & \\
\hline AT & Vermont & Ride Guide-10/02 & & & $x$ & & $x$ & & & & \\
\hline CAT & Las Vegas & Ride Guide-9/02 & & & $\mathrm{x}$ & & & & & $\mathrm{x}$ & \\
\hline C-UMTD & Champaign, IL & Ride Guide-8/02 & & & & $x$ & & & & & $x$ \\
\hline CYRide & Des Moines & Complete System Map-8/02 & & & $x$ & & & & $x$ & & \\
\hline DART & Dallas & Individual Rte Sch/Map-5/02 & & & $x$ & & & & $\mathrm{x}$ & & \\
\hline DTA & Daluth, MN & Individual Rte Sch/Maps-5/02 & & & & $\mathrm{x}$ & & & $x$ & & \\
\hline GFT & Great Falls, MT & Ride Guide-9/02 & & & $x$ & & & & $x$ & & \\
\hline IndyGo & Indianopolis & Individual Rte Sch/Maps-11/88 & & $x$ & & & & & $x$ & & \\
\hline MBTA & Boston & Individual Rte Sch/Maps-8/02 & & & & & & & & $\mathrm{x}$ & \\
\hline MVTA & Burnsville, MN & Individual Rte Sch/Map-6/02 & & $x$ & & & & & & & $x$ \\
\hline TARC & Louisville, KY & Individual Rte Sch/Map-5/02 & & $\mathrm{X}$ & & & & & $\mathrm{X}$ & & \\
\hline
\end{tabular}


Table 6 identifies what information is depicted in individual route materials for those systems in the database that use individual route schedules and maps. In the case of the materials included in the database, all include a timetable or schedule and map for each route.

Table 6: Transit Schedule/Map Inventory: Format (Systems with Individual Route Maps)

\begin{tabular}{|c|c|c|c|c|c|}
\hline \multirow[b]{2}{*}{$\begin{array}{l}\text { Transit } \\
\text { System }\end{array}$} & \multirow[b]{2}{*}{ Location } & \multirow[b]{2}{*}{ Type } & \multicolumn{3}{|c|}{ Individual Rte. Schedules/Maps } \\
\hline & & & $\begin{array}{l}\text { Timetable } \\
\text { and Map }\end{array}$ & $\begin{array}{c}\text { Timetable } \\
\text { only }\end{array}$ & Map only \\
\hline BCT & Broward & Individual Route Sch/Map-8/02 & $\mathrm{X}$ & & \\
\hline HARTline & Hillsborough & Individual Route Sch/Map-5/01 & $\mathrm{x}$ & & \\
\hline JTA & Jacksonville & Individual Route Sch/Map-7/99 & $\mathrm{x}$ & & \\
\hline LAMT & Lakeland & Individual Rte Sch/Map-10/00 & $\mathrm{x}$ & & \\
\hline LeeTran & Lee County & Individual Rte Sch/Map-9/00 & $\mathrm{x}$ & & \\
\hline LYNX & Orlando area & Indivdual Rte Sch/Map-12/99 & $\mathrm{x}$ & & \\
\hline MDT & Miami-Dade & Individual Rte Sch/Map-4/01 & $\mathrm{x}$ & & \\
\hline Palm Tran & Palm Beach & Individual Rte Sch/Map-10/01 & $\mathrm{x}$ & & \\
\hline PCPT & Pasco & Individual Rte Sch/Map-1/00 & $\mathrm{x}$ & & \\
\hline PSTA & Pinellas & Individual Rte Sch/Map-12/00 & $\mathrm{x}$ & & \\
\hline WHAT & Winter Haven & Individual Rte Sch/Map-2/00 & $\mathrm{x}$ & & \\
\hline TARC & Louisville, KY & Individual Rte Sch/Map-5/02 & $\mathrm{x}$ & & \\
\hline MBTA & Boston & Individual Rte Sch/Maps-8/02 & $\mathrm{x}$ & & \\
\hline MVTA & Burnsville, $\mathrm{MN}$ & Individual Rte Sch/Map--6/02 & $\mathrm{x}$ & & \\
\hline DTA & Daluth, MN & Individual Rte Sch/Maps-5/02 & $\mathrm{x}$ & & \\
\hline IndyGo & Indianopolis & Individual Rte Sch/Maps-11/88 & $\mathrm{x}$ & & \\
\hline DART & Dallas & Individual Rte Sch/Map-5/02 & $\mathrm{x}$ & & \\
\hline
\end{tabular}

Table 7 identifies what information is included in the system ride guides or multiroute guides for those transit agencies in the database that use ride guides. There are generally two variations in the layout of schedules and maps in ride guides. As shown in Table 7, 10 of the transit systems that use ride guides include separate schedules for each route and one system-wide map. The remaining 8 of the transit agencies that use ride guides include separate schedules for each route, as well as an individual map for each of those routes. It appears that the use of the system-wide map and separate schedules in a ride guide has a slight edge in terms of preference among the transit agencies in the database; however, there is no clear evidence that transit agencies prefer one layout method to another. While it is not evident in Table 7, several of the systems which have ride guides with separate schedules for each route and one system-wide map do so because they have very few routes in the first place. 


\section{Table 7: Transit Schedule/Map Inventory: Format (Systems with Ride Guides)}

\begin{tabular}{|c|c|c|c|c|c|c|}
\hline \multirow[b]{2}{*}{ Transit System } & \multirow[b]{2}{*}{ Location } & \multirow[b]{2}{*}{ Type } & \multicolumn{4}{|c|}{ Ride Guides or Multi-Route Guides } \\
\hline & & & $\begin{array}{c}\text { Timetable } \\
\text { only }\end{array}$ & $\begin{array}{l}\text { Separate } \\
\text { Time } \\
\text { Tables \& } \\
\text { System } \\
\text { Map }\end{array}$ & $\begin{array}{c}\text { Separate } \\
\text { Time } \\
\text { Tables \& } \\
\text { Individual } \\
\text { Maps }\end{array}$ & $\begin{array}{c}\text { Map(s) } \\
\text { only }\end{array}$ \\
\hline AppalCART & Boone, NC & Schedules and Routes-8/02 & & $\mathrm{x}$ & & \\
\hline AT & Vermont & Timetable and Map-1/02 & & $\mathrm{x}$ & & \\
\hline Bay Town Trolley & Panama City & Ride Guide- $9 / 5 / 00$ & & $\mathrm{x}$ & & \\
\hline CAT & Las Vegas & Ride Guide-9/02 & & & $\mathrm{x}$ & \\
\hline C-UMTD & Champaign, IL & Ride Guide-8/02 & & & $\mathrm{x}$ & \\
\hline CYRide & Des Moines & Ride Guide-8/02 & & $\mathrm{X}$ & & \\
\hline ECAT & Escambia & Ride Guide-11/01 & & & $\mathrm{x}$ & \\
\hline GFT & Great Falls, MT & Ride Guide-9/02 & & $\mathrm{x}$ & & \\
\hline Key West & Key West & Bus Schedule & & $\mathrm{x}$ & & \\
\hline LYNX & Orlando area & Schedule Book-5/01 & & & $\mathrm{x}$ & \\
\hline MCAT & Manatee & Ride Guide-1/01 & & & $\mathrm{x}$ & \\
\hline OCT & Okaloosa & Ride Guide-FWB Wave only & & $\mathrm{x}$ & & \\
\hline PalmTran & Palm Beach & Riders Guide- $10 / 00$ & & & $\mathrm{x}$ & \\
\hline RTS & Gainesville & Ride Guide-1/01 & & & $\mathrm{X}$ & \\
\hline SCAT & Sarasota & Ride Guide-Spring 2000 & & $\mathrm{X}$ & & \\
\hline SCAT & Brevard & Ride Guide-6/00 & & & & \\
\hline SunTran & Ocala & System Route and Map-11/99 & & $\mathrm{X}$ & & \\
\hline TalTran & Tallahassee & Ride Guide-8/00 & & & $\mathrm{X}$ & \\
\hline VOTRAN & Volusia & Area Rte Sch/Maps-1/00 & & $\mathrm{X}$ & & \\
\hline
\end{tabular}

Table 8 addresses two additional variations in schedule layout. Both the color scheme of schedules and the alignment of stops on the schedule are compared among the transit information materials in the database. The majority of the schedules in the database are multi-color (19). Twelve of the schedules in the database have two colors and the remaining are black and white (5). Six of the schedules in the database include photos. A clear majority of the schedules in the database present the timetable with horizontal stops (32 of 36). 


\section{Table 8 -Transit Schedule/Map Inventory: Color Scheme and Stop Alignment}

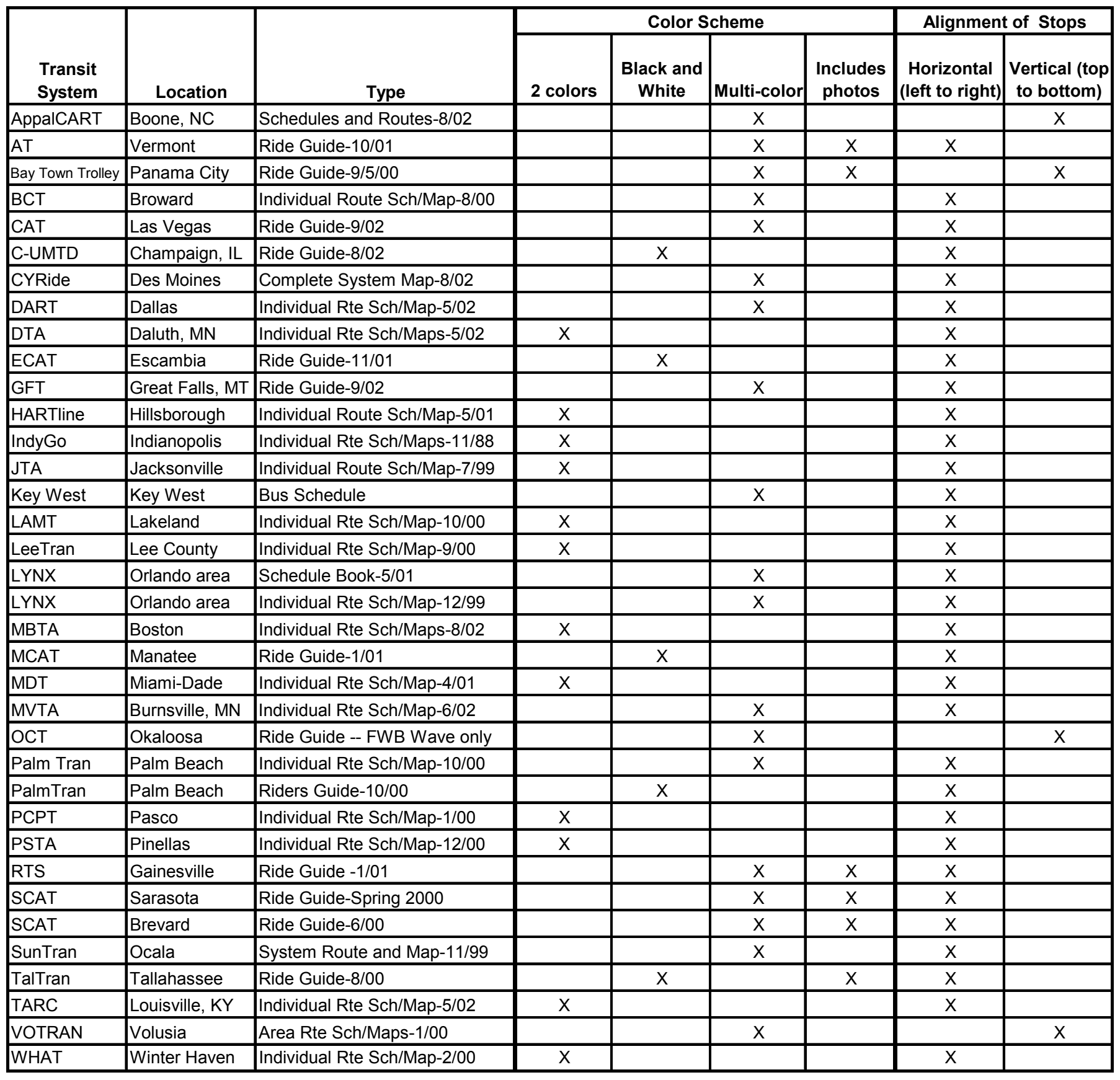


Table 9 describes the features of the system-wide maps for those agencies that have a stand-alone system map. The table illustrates how the routes are identified on the map (by color, number, and/or name); whether there is a legend on the map; whether transfer points and points of interest are identified on the map; and finally, the table also identifies those system maps for which the north directional arrow is present and positioned up. The majority of the 17 maps in the database identify the various routes by color, number, and name. Specifically, 14 maps identified routes by color, 16 by number, 10 by name, and 9 identified routes on the map using colors, numbers, and names. All but two of the maps in the database had a legend. The detail level of the legends varied greatly. Points of interest were used on 10 of the maps. Some points of interest were symbolized on the map, while some agencies provided a list of points of interest with corresponding routes of access. Nearly all of the maps utilized a north directional symbol. Only two did not have directional guides on the map.

Similar comparisons are made in Table 10, except the system-wide maps for these agencies are in the ride guide, rather than stand-alone. Again, most of the routes are identified by color (16 of 17). Thirteen of the 17 identify routes by number. Only 7 identify routes on the map by name. Unlike the stand-alone maps, very few systems represent routes by colors, numbers, and names.

Eleven of the agencies included a legend with their map; however, the legends typically were not as detailed as the legends for stand-alone maps. Points of interest were displayed on 11 of 17 maps and 12 of 17 utilized north directional arrows that were positioned upwards. 
Table 9 - Transit Map Inventory:

Map Features of Stand-Alone System Maps

\begin{tabular}{|c|c|c|c|c|c|c|c|c|c|c|}
\hline \multirow[b]{2}{*}{$\begin{array}{l}\text { Transit } \\
\text { System }\end{array}$} & \multirow[b]{2}{*}{ Location } & \multirow[b]{2}{*}{ Type } & \multicolumn{8}{|c|}{ Map Features } \\
\hline & & & $\begin{array}{c}\text { Stand } \\
\text { Alone } \\
\text { Map }\end{array}$ & $\begin{array}{c}\text { Routes } \\
\text { Identified } \\
\text { by Color } \\
\text { on Map } \\
\end{array}$ & \begin{tabular}{|c} 
Routes \\
Identified \\
by Number \\
on Map \\
\end{tabular} & $\begin{array}{c}\text { Routes } \\
\text { Identified } \\
\text { by Name } \\
\text { on Map }\end{array}$ & $\begin{array}{c}\text { Legend } \\
\text { Included }\end{array}$ & $\begin{array}{c}\text { Transfer } \\
\text { locations } \\
\text { identified } \\
\end{array}$ & $\begin{array}{c}\text { Points of } \\
\text { Interest } \\
\text { identified }\end{array}$ & $\begin{array}{c}\text { North arrow } \\
\text { positioned } \\
\text { up }\end{array}$ \\
\hline BCT & Broward & Transit System Map -- 8/2000 & $x$ & $\mathrm{x}$ & $x$ & $\mathrm{x}$ & & $x$ & & $\mathrm{X}$ \\
\hline CTA & Chicago, IL & Bus and Rail Map-Spr 2002 & $\mathrm{x}$ & $x$ & $\mathrm{x}$ & $\mathrm{x}$ & $x$ & $\mathrm{x}$ & $x$ & $x$ \\
\hline DART & Dallas & System Map-5/01 & $\mathrm{X}$ & $\mathrm{x}$ & $\mathrm{X}$ & $x$ & $x$ & & $\mathrm{x}$ & $x$ \\
\hline ECAT & Escambia & Ride Guide-11/01 & $x$ & $x$ & $\mathrm{x}$ & $x$ & $x$ & $x$ & $x$ & \\
\hline ETS & Edmonton (Canada) & System Map-Wntr/Spr 2002 & $\mathrm{x}$ & & $\mathrm{x}$ & $x$ & $x$ & $x$ & & \\
\hline HARTline & Hillsborough & Transit Guide-9/02 & $x$ & $x$ & $x$ & $x$ & $x$ & $x$ & & $x$ \\
\hline IndyGo & Indianopolis & System Map-8/01 & $x$ & $\mathrm{x}$ & $x$ & $x$ & $x$ & & $x$ & $x$ \\
\hline JTA & Jacksonville & Transit Guide-10/00 & $x$ & & & & & & & $\mathrm{x}$ \\
\hline LeeTran & Lee County & System Map & $\mathrm{x}$ & $x$ & $\mathrm{x}$ & & $x$ & $x$ & & $\mathrm{x}$ \\
\hline MBTA & Boston, MA & System Map & $\mathrm{x}$ & $x$ & $\mathrm{x}$ & $\mathrm{X}$ & $x$ & $x$ & $x$ & $x$ \\
\hline MDT & Miami-Dade & Transit Map-2/01 & $x$ & $x$ & $\mathrm{x}$ & & $x$ & & $x$ & $x$ \\
\hline MTA & Montgomery, MD & Transit Map-9/02 & $\mathrm{x}$ & & $\mathrm{x}$ & & $x$ & $x$ & & $x$ \\
\hline PalmTran & Palm Beach & System Map-10/00 & $x$ & $x$ & $x$ & & $x$ & $x$ & $x$ & $x$ \\
\hline RTA & Chicago Area & Regional Transit Map-2002 & $x$ & $x$ & $x$ & & $x$ & $x$ & $x$ & $\mathrm{x}$ \\
\hline TARC & Louisville, KY & Transit Map-1/02 & $\mathrm{X}$ & $\mathrm{X}$ & $\mathrm{X}$ & $x$ & $\mathrm{X}$ & $\mathrm{x}$ & $\mathrm{x}$ & $x$ \\
\hline The Bus & Oahu, HI & System Map-Winter 2002 & $X$ & $x$ & $\mathrm{X}$ & & $x$ & & & $x$ \\
\hline WHAT & Winter Haven & System Map & $X$ & $x$ & $\mathrm{X}$ & $x$ & $x$ & & $X$ & $X$ \\
\hline
\end{tabular}


Table 10 - Transit Map Inventory:

Map Features of System Maps in Ride Guides

\begin{tabular}{|c|c|c|c|c|c|c|c|c|c|c|}
\hline \multirow[b]{2}{*}{ Transit System } & \multirow[b]{2}{*}{ Location } & \multirow[b]{2}{*}{ Type } & \multicolumn{8}{|c|}{ Map Features } \\
\hline & & & $\begin{array}{l}\text { Map in } \\
\text { Ride } \\
\text { Guide }\end{array}$ & $\begin{array}{c}\text { Routes } \\
\text { Identified } \\
\text { by Color } \\
\text { on Map } \\
\end{array}$ & $\begin{array}{c}\text { Routes } \\
\text { Identified } \\
\text { by Number } \\
\text { on Map }\end{array}$ & $\begin{array}{c}\text { Routes } \\
\text { Identified } \\
\text { by Name } \\
\text { on Map } \\
\end{array}$ & $\begin{array}{c}\text { Legend } \\
\text { Included }\end{array}$ & $\begin{array}{c}\text { Transfer } \\
\text { locations } \\
\text { identified } \\
\end{array}$ & $\begin{array}{l}\text { Points of } \\
\text { Interest } \\
\text { identified }\end{array}$ & $\begin{array}{c}\text { North arrow } \\
\text { positioned } \\
\text { up }\end{array}$ \\
\hline AppalCART & Boone, NC & Complete System Map-8/02 & $\mathrm{X}$ & $\mathrm{X}$ & $\mathrm{X}$ & & $\mathrm{X}$ & & & \\
\hline AT & Vermont & Ride Guide-10/01 & $x$ & $x$ & & $x$ & $x$ & $\mathrm{x}$ & & \\
\hline Bay Town Trolley & Panama City & Ride Guide-9/00 & $\mathrm{X}$ & $\mathrm{X}$ & & $\mathrm{x}$ & $\mathrm{X}$ & $\mathrm{X}$ & $\mathrm{X}$ & $\mathrm{X}$ \\
\hline CAT & Las Vegas & Ride Guide-9/02 & $\mathrm{x}$ & $x$ & $\mathrm{x}$ & & & & & $\mathrm{x}$ \\
\hline C-UMTD & Champaign, IL & Ride Guide-8/02 & $x$ & & $x$ & & & & $x$ & $x$ \\
\hline CYRide & Des Moines & Complete System Map-8/02 & $\mathrm{x}$ & $\mathrm{x}$ & $\mathrm{x}$ & & $\mathrm{x}$ & $\mathrm{x}$ & $\mathrm{x}$ & $\mathrm{x}$ \\
\hline GFT & Great Falls, MT & Ride Guide-9/02 & $x$ & $x$ & $x$ & $x$ & $x$ & $x$ & $x$ & $x$ \\
\hline Key West & Key West & Bus Schedule & $x$ & $x$ & & & & & & \\
\hline LYNX & Orlando area & Schedule Book-5/01 & $x$ & $\mathrm{x}$ & $\mathrm{x}$ & $x$ & $\mathrm{X}$ & $\mathrm{X}$ & $\mathrm{X}$ & $\mathrm{X}$ \\
\hline MCAT & Manatee & Ride Guide-1/01 & $x$ & $\mathrm{x}$ & $\mathrm{X}$ & & $x$ & & $\mathrm{x}$ & $\mathrm{x}$ \\
\hline OCT & Okaloosa & Ride Guide-FWB Wave only & $\mathrm{x}$ & $\mathrm{x}$ & & & & & $\mathrm{x}$ & \\
\hline RTS & Gainesville & Ride Guide-1/01 & $x$ & $x$ & $x$ & & & & & $x$ \\
\hline SCAT & Sarasota & Ride Guide-Spring 2000 & $\mathrm{x}$ & $\mathrm{x}$ & $\mathrm{x}$ & & $\mathrm{x}$ & $\mathrm{x}$ & $x$ & $\mathrm{x}$ \\
\hline SCAT & Brevard & Ride Guide-6/00 & $x$ & $x$ & $x$ & $x$ & & & & $x$ \\
\hline SunTran & Ocala & System Route and Map-11/99 & $x$ & $x$ & $\mathrm{X}$ & $x$ & $\mathrm{X}$ & $x$ & $\mathrm{x}$ & $\mathrm{x}$ \\
\hline TalTran & Tallahassee & Ride Guide- $8 / 00$ & $\mathrm{x}$ & $x$ & $\mathrm{x}$ & & $\mathrm{x}$ & $\mathrm{x}$ & $\mathrm{x}$ & $\mathrm{x}$ \\
\hline VOTRAN & Volusia & Area Rte Sch/Maps-1/00 & $x$ & $x$ & $\mathrm{X}$ & $\mathrm{x}$ & $x$ & $\mathrm{X}$ & $x$ & \\
\hline
\end{tabular}




\section{SECTION THREE Process for Design Element Selection}

Once the design elements were identified, those that would be tested in the secondary project needed to be selected. In determining which elements would be evaluated, staff considered the feasibility of testing each design element, how expensive performing the test would be, whether participants in the original field test noted difficulty with the particular design element, and the degree to which the design element is perceived to be important to a non-user's transit trip planning ability.

Table 11 categorizes each previously identified design element by degree to which evaluating variations in a field test is feasible. Those design elements that can be more feasibly evaluated are those that have precise options regarding variation. For instance, Front/Back Layout will involve two variations with very little chance of secondary variations. However, evaluating the Use of Color (Functional) may involve infinitely more considerations, such as which colors to use in identifying routes and which specific variations can be used to contrast routes by color. As noted in Table 11, most of the design elements identified in this project are considered most feasible to evaluate. The few that are labeled "feasible" will require more consideration as they involve possible secondary variations (e.g. when comparing system maps versus individual route maps, the detail level of the map may also vary). As noted earlier, it is important to minimize secondary variations in the field test, as the goal of isolating a design element could be lost otherwise. 


\section{Table 11: Design Element Evaluation -- Feasibility}

\begin{tabular}{|l|l|}
\hline \multicolumn{1}{|c|}{ More Feasible } & \multicolumn{1}{c|}{ Feasible } \\
\hline Front/Back Layout & Material Format (Schedules and Maps) \\
Stop Alignment & Material Format (Maps) \\
Day Scheduling & Map Details \\
Time Scheduling (a.m./p.m.) & Use of Color (Functional) \\
Time Scheduling (Departure Time) & Font Size \\
Use of Color (Aesthetic) & \\
Legend & \\
Time Point Identification & \\
Transfer Points & \\
Directional Symbol & \\
\hline
\end{tabular}

Table 12 addresses the costs of evaluating each design element. In the table the various design elements are categorized as least expensive, moderately expensive, and most expensive. Those design elements that can be incorporated into the standard testing materials relatively inexpensively are considered least expensive. An example of this might be whether or not a legend is used on a map. In such a case, a legend variation would have very little impact on the design and production costs of the testing materials.

Those design element variations that involve some moderate manipulation of testing material layout are considered to be moderately expensive. Moderately expensive design elements require more manipulation to the base prototype materials, but are not as expensive as those design element variations that require significant manipulation. Examples of significant manipulations are the addition of color to material and comparing ride guide format to individual route format.

\section{Table 12: Design Element Evaluation - Cost to Test}

\begin{tabular}{|l|l|l|}
\hline \multicolumn{1}{|c|}{ Least Expensive } & \multicolumn{1}{|c|}{ Moderately Expensive } & \multicolumn{1}{c|}{ Most Expensive } \\
\hline Stop Alignment & Front/Back Layout & Material Format (Schedules \\
Day Scheduling & Font Size & and Maps) \\
Time Scheduling (a.m./p.m.) & Transfer Point & Material Format (Maps) \\
Time Scheduling (Departure) & Time Point Identification & Use of Color (Aesthetic) \\
Legend & & Use of Color (Functional) \\
Directional Symbol & & Map Details \\
\hline
\end{tabular}


In Table 13, the design elements are divided by whether or not participants in the original pilot and field tests noted difficulty with that design element. The participants were provided opportunities after the trip-planning portion of the pilot or field test to provide insight into what made planning the transit trips easier or more difficult.

\section{Table 13: Design Element Evaluation -- Noted Difficulty in Original Tests}

\begin{tabular}{|l|l|l|}
\hline Significant Difficulty Noted & Moderate Difficulty Noted & Little-to-No Difficulty Noted \\
\hline Material Format (Schedules & Font Size & Stop Alignment \\
and Maps) & Time Scheduling (Departure) & Use of Color (Aesthetic) \\
Material Format (Maps) & Time Point Identification & Legend \\
Front/Back Layout & Map Details & Directional Symbol \\
Time Scheduling (a.m./p.m.) & Transfer Points & Day Scheduling \\
& Use of Color (Functional) & \\
& & \\
\hline
\end{tabular}

Table 14 outlines what design elements are perceived to have the greatest impact on a customer's ability to complete the transit trip planning process. This perception is noted through the results of the original field test results, dialogue with transit agency representatives and others interested in the outcome of this project. These perceptions do not imply that there are quantifiable instances of these design elements impacting transit trip planning. Instead, Table 14 suggests that there has been significant discussion to imply that those design elements proposed for evaluation in this project are perceived to be important the trip planning process. On the other hand, many transit professionals admit to being unsure of how important some of the design elements have on transit trip planning. This illustrates how providing statistically sound evidence on the impact of these design elements could assist transit agency marketing personnel. 
Table 14: Design Element Evaluation -

Perceived Importance to Trip Planning

\begin{tabular}{|c|c|c|}
\hline $\begin{array}{l}\text { Strong Perception } \\
\text { of Importance }\end{array}$ & $\begin{array}{c}\text { Moderate Perception } \\
\text { of Importance }\end{array}$ & $\begin{array}{l}\text { Little Perception } \\
\text { of Importance }\end{array}$ \\
\hline $\begin{array}{l}\text { Material Formats (Schedules } \\
\text { and Maps) } \\
\text { Material Format (Maps) } \\
\text { Front/Back Layout } \\
\text { Map Details } \\
\text { Time Point Identification } \\
\text { Use of Color (Functional) } \\
\text { Time Scheduling (a.m./p.m.) }\end{array}$ & $\begin{array}{l}\text { Stop Alignment } \\
\text { Day Scheduling } \\
\text { Time Scheduling (Departure) } \\
\text { Legend } \\
\text { Font Size } \\
\text { Transfer Points }\end{array}$ & $\begin{array}{l}\text { Use of Color (Aesthetic) } \\
\text { Directional Symbol }\end{array}$ \\
\hline
\end{tabular}

In an effort to identify which design elements should be evaluated in the secondary project, CUTR researchers primarily considered those criteria that would represent the concerns and perspective of the transit user. For instance, strong perception of importance to trip planning and significant difficulty noted on the original test are reflective of the transit users' value of testing each design element. On the other hand, transit users are less concerned with how expensive it is to test for certain design elements or how feasible it will be to produce testing variations. Table 15 distributes the design elements into tiers, which identify those that will definitely be evaluated in the secondary project (probably be evaluated, possibly be evaluated, and will not be evaluated). Those that will definitely be evaluated are those design elements that meet either of the criteria that are considered consumer-relevant (i.e. strongly perceived to be important to transit users or posed significant difficulty for subjects in the observational tests in the original project). Design elements that will probably be evaluated are those that meet both the feasibility and cost criteria. The remaining design elements meet only one of the feasibility or cost criteria or neither of them, and they will not be evaluated in the secondary project. 
Table 15: Design Element Selection Matrix

\begin{tabular}{|c|c|c|c|c|c|}
\hline Element & $\begin{array}{c}\text { Strong } \\
\text { Perception } \\
\text { of } \\
\text { Importance }\end{array}$ & $\begin{array}{c}\text { Significant } \\
\text { Difficulty in } \\
\text { Original } \\
\text { Project }\end{array}$ & $\begin{array}{c}\text { Most } \\
\text { Feasible to } \\
\text { Test }\end{array}$ & $\begin{array}{c}\text { Inexpensive } \\
\text { to Test }\end{array}$ & Tier \\
\hline Time Scheduling (a.m./p.m.) & $x$ & $x$ & $x$ & $x$ & \multirow{7}{*}{ 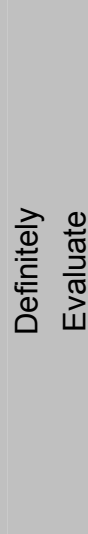 } \\
\hline $\begin{array}{l}\text { Material Format (Schedules and } \\
\text { Maps) }\end{array}$ & $x$ & $x$ & $x$ & & \\
\hline Material Format (Maps) & $X$ & $X$ & $X$ & & \\
\hline Back/Front Layout & $x$ & $\mathrm{X}$ & $\mathrm{X}$ & & \\
\hline Time Point Identification & $x$ & & $\mathrm{x}$ & & \\
\hline Use of Color (Functional) & $x$ & & & & \\
\hline Map Detail & $X$ & & & & \\
\hline Stop Alignment & & & $x$ & $x$ & \multirow{5}{*}{ 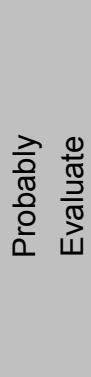 } \\
\hline Day Scheduling & & & $x$ & $x$ & \\
\hline $\begin{array}{l}\text { Time Scheduling (Departure } \\
\text { Time) }\end{array}$ & & & $x$ & $x$ & \\
\hline Legend & & & $x$ & $x$ & \\
\hline Directional Symbol & & & $x$ & $x$ & \\
\hline Use of Color (Aesthetic) & & & $x$ & & \multirow{3}{*}{ 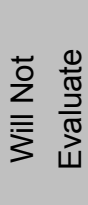 } \\
\hline Transfer Point Identification & & & $x$ & & \\
\hline Font Size & & & & & \\
\hline
\end{tabular}




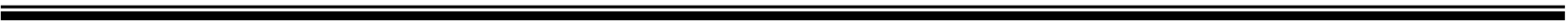

Assessment of Transit Information Materials and

Development of Criteria for Prototype Transit Materials 


\section{SECTION FOUR \\ Next Steps}

The follow-up or secondary project to Assessment of Operational Barriers and Impediments to Transit Use, will potentially provide extremely useful information regarding best practices in transit information materials design. The secondary project will identify those design elements of written transit information materials that provide the greatest utility to users and non-users when planning a transit trip. Ultimately, those design elements will be incorporated into prototype materials that will serve as models to transit agencies.

This project will involve the design and production of prototype transit information materials that will be field tested among transit non-users to determine their effectiveness as tools for transit trip planning. Several versions of the prototype materials will be developed and tested, based on the design element variations identified in Section Three of this intermediary report.

The initial steps for this project involve conceptualizing the layout and development of the prototype bus schedules and maps. Besides those conducting the research, this process will also involve several graphic and GIS/mapping staff at CUTR. The standard prototype maps and schedules will consist of the same base information, such as routes, service area, service frequency. However, variations to the standard information will be developed to test the various design elements. For instance, the standard prototype maps will be modified to vary in detail to test how various map detail levels impact effectiveness. In another example, the standard prototype maps and schedules will be transformed into an all-in-one ride guide, so that the effectiveness of individual route information and ride guides can be compared.

Based on the number of design element variations identified in Sections Two and Three of this report, there will be at least 25 variations to the standard prototype maps and schedules. Each variation will be illustrated individually to ensure that the test results will provide some definitive conclusions about its effectiveness in transit trip planning. 
As in the Assessment of Operational Barriers and Impediments to Transit Use report, the methodology used to evaluate the effectiveness of the design element variations will involve the collection and analysis of quantitative and qualitative data through field tests.

The methodology specifically involves developing a sample made up of individuals with little to no transit experience to participate in transit trip planning activities using various prototype materials. Field test administrators will facilitate the test and observe the verbal and physical reactions of each participant as he or she completes the trip planning activity. In addition, at the conclusion of each trip planning activity the test administrator will ask several questions to gauge each participant's experience.

A sample size between 150 and 250 participants is needed in order to test the 12 selected design elements (see Table 10). The larger sample size is obviously preferable; however, 150 subjects can be used effectively. A sample size in this range will prevent carry-over and sequential effects by assigning different participants to each variation of the design element, controlling for sequence and order of presentation. The experimental design will be a between subject design in that a participant will be randomly assigned to only one variation of a design element and not every variation possible. The large sample size ensures that each pair of trip planning tasks will be completed several times in various order and controls for any carry-over or sequential effects which may be present.

In developing the sample for the field test, CUTR utilized methods similar to those for the original Barriers project. Mall intercept recruitment will be used to identify field test participants who represent a wide range of demographic characteristics and who have little to no experience using transit. Again, CUTR will contract with market research companies in Tampa area shopping malls to carry out participant recruitment. In addition, each participant will be offered a $\$ 5.00$ incentive as compensation for his or her time. Each participant will participate in two trip-planning activities that will involve a total of 30-40 minutes.

CUTR will conduct, prior to the observational field tests, at least two pilot studies to test the usefulness of the trip planning tasks and materials. Suggested pilot 
study sample groups include students at the University of South Florida and participants at senior centers or other sites where elderly populations frequent. These pilot studies will be conducted in addition to a pilot study with transit professionals and students at CUTR. Not only will the CUTR pilot study group be instrumental in testing the trip planning tasks and materials, it will also provide constructive feedback from the point of view of transit professionals. On the other hand, pilot study groups with students and seniors who have little-to-no transit experience will be useful in testing the effectiveness of the materials and will allow the researchers to determine if the tools are designed to provide useful results.

In the field test, each trip-planning task (each participant will have two) will be scored according to the choices made by participants in relation to the following data elements (dependent variables):

1. Ability to travel from origin to intended destination

2. On-time arrival to destination

3. Origin bus route

4. Origin bus stop

5. Origin time

6. Transfer bus route

7. Transfer bus stop

8. Transfer time

9. Destination bus stop

10. Destination time

A composite score, consisting of the scores for each of these dependent variables will be assigned to each transit trip planning task attempted by participants. In addition, statistical tests will be applied to the quantitative data to determine the statistical significance of demographic characteristics, socioeconomic characteristics, and design element variations on the final score associated with transit trip planning tasks. In addition, the qualitative interview and observational data collected during the trip planning activities will be analyzed as self-reported measures. 
At the completion of the qualitative and quantitative data analysis of the field test results, the design element variations which impact a person's ability to effectively plan a transit trip using schedules and maps should be identifiable. CUTR researchers hope that the results will provide sufficient support to encourage the use of certain design element variations over others, when considering the effectiveness from the users' and potential users' points of view. 